\title{
A conservation palaeobiological approach to assess faunal response of threatened biota under natural and anthropogenic environmental change
}

\author{
Sabrina van de Velde ${ }^{1, *}$, Elisabeth L. Jorissen ${ }^{2, *}$, Thomas A. Neubauer ${ }^{1,3}$, Silviu Radan $^{4}$, Ana Bianca Pavel ${ }^{4}$, \\ Marius Stoica $^{5}$, Christiaan G. C. Van Baak ${ }^{6}$, Alberto Martínez Gándara ${ }^{7}$, Luis Popa ${ }^{7}$, Henko de Stigter ${ }^{8,2}$, \\ Hemmo A. Abels ${ }^{9}$, Wout Krijgsman ${ }^{2}$, and Frank P. Wesselingh ${ }^{1}$ \\ ${ }^{1}$ Naturalis Biodiversity Center, P.O. Box 9517, 2300 RA Leiden, the Netherlands \\ ${ }^{2}$ Palaeomagnetic Laboratory "Fort Hoofddijk", Faculty of Geosciences, Utrecht University, Budapestlaan 17, \\ 3584 CD Utrecht, the Netherlands \\ ${ }^{3}$ Department of Animal Ecology \& Systematics, Justus Liebig University, \\ Heinrich-Buff-Ring 26-32 IFZ, 35392 Giessen, Germany \\ ${ }^{4}$ National Institute of Marine Geology and Geoecology (GeoEcoMar), \\ 23-25 Dimitrie Onciul St., 024053 Bucharest, Romania \\ ${ }^{5}$ Department of Geology, Faculty of Geology and Geophysics, University of Bucharest, \\ Bălcescu Bd. 1, 010041 Bucharest, Romania \\ ${ }^{6}$ CASP, West Building, Madingley Rise, Madingley Road, CB3 0UD, Cambridge, UK \\ ${ }^{7}$ Grigore Antipa National Museum of Natural History, Sos. Kiseleff Nr. 1, 011341 Bucharest, Romania \\ ${ }^{8}$ NIOZ Royal Netherlands Institute for Sea Research, Department of Ocean Systems, 1790 AB Den Burg, the Netherlands \\ ${ }^{9}$ Department of Geosciences and Engineering, Delft University of Technology, Stevinweg 1, 2628 CN Delft, the Netherlands \\ *These authors contributed equally to this work.
}

Correspondence: Sabrina van de Velde (sabrina.vandevelde@ naturalis.nl) and Elisabeth L. Jorissen (e.1.jorissen@uu.nl)

Received: 10 January 2019 - Discussion started: 31 January 2019

Revised: 26 April 2019 - Accepted: 16 May 2019 - Published: 17 June 2019

\begin{abstract}
Palaeoecological records are required to test ecological hypotheses necessary for conservation strategies as short-term observations can insufficiently capture natural variability and identify drivers of biotic change. Here, we demonstrate the importance of an integrated conservation palaeobiology approach when making validated decisions for conservation and mitigating action. Our model system is the Razim-Sinoie lake complex (RSL) in the Danube Delta (Black Sea coast, Romania), a dynamic coastal lake system hosting unique Pontocaspian mollusc species that are now severely under threat. The Pontocaspians refer to an endemic species group that evolved in the Black Sea and Caspian Sea basins under reduced salinity settings over the past few million years. The natural, pre-industrial RSL contained a salinity gradient from fresh to mesohaline (18 ppm) until human intervention reduced the inflow of mesohaline Black Sea water into the lake system. We reconstruct the evolution of the RSL over the past 2000 years from inte-
\end{abstract}

grated sedimentary facies and faunal analyses based on 11 age-dated sediment cores and investigate the response of mollusc species and communities to those past environmental changes. Three species associations ("marine", "Pontocaspian" and "freshwater") exist and their spatio-temporal shifts through the system are documented. Variable salinity gradients developed, with marine settings (and faunas) dominating in the southern part of the system and freshwater conditions (and faunas) in the northern and western parts. Pontocaspian species have mostly occurred in the centre of the RSL within the marine-freshwater salinity gradient. Today, freshwater species dominate the entire system, and only a single Pontocaspian species (Monodacna colorata) is found alive. We show that the human-induced reduced marine influence in the system has been a major driver of the decline of the endemic Pontocaspian biota. It urges improved conservation action by re-establishing a salinity gradient in the lake system to preserve these unique species. 


\section{Introduction}

The emerging field of conservation palaeobiology aims to evaluate palaeobiological records to make informed contributions to biodiversity conservation. A spectrum of conservation palaeobiology studies exists, covering different timescales as well as biota (Dietl and Flessa, 2011; VegasVilarrubia et al., 2011; Birks, 2012; Kosnik and Kowalewski, 2016). These provide important insights into the resilience of species and communities under environmental change. Yet, few studies provide long-term observations and quantitative and environmental data, as well as direct guidance on the conservation of threatened habitats and communities today (Cramer et al., 2017). A relevant conservation palaeobiology model system should ideally include species and communities that are currently under threat, together with a high spatio-temporal resolution geological record of past habitat dynamics, and should contain both natural variation and anthropogenic influence. Altogether the data should not only focus on scientific observations and understanding but also contribute to conservation policies with relevant proposals for ecosystem management (Helama et al., 2007; VegasVilarrubia et al., 2011; Albano et al., 2016; Kosnik and Kowalewski, 2016; Martinelli et al., 2017).

Here, we report a unique conservation palaeobiology model system that combines a detailed historical record of environmental and faunal change with relevant proposals for conservation. The Razim-Sinoie lake complex (RSL) consists of a set of coastal lakes and lagoons located in the south of Danube Delta along the Black Sea in Romania (Fig. 1). The system has a dynamic late Holocene history of lake and barrier formation and of connectivity with the Danube River, as well as the Black Sea, that affected salinity gradients (Panin and Jipa, 2002; Giosan et al., 2006; Gâstescu, 2009; Romanescu, 2013; Panin et al., 2016; VespremeanuStroe et al., 2017). Since ancient Greek times, shipping ports have been present in the RSL (Breţcan et al., 2008; Romanescu, 2013; Bony et al., 2015), and from 1800 onwards, active human modification of the river and marine outlets shaped the system towards its present state (Breţcan et al., 2008, 2009). The RSL is known as prime habitat for currently threatened Pontocaspian species (Grossu, 1973; Popa et al., 2009, 2010). Within the area of the Danube Delta, a strong reduction of Pontocaspian species occurrences has been documented for the past decades (Alexandrov et al., 2004; Popa et al., 2009). Before 1956, about $70 \%$ of the species living in the benthic zone had a Pontocaspian origin, and remaining species belonged to other brackish or freshwater species (Teodorescu-Leonte et al., 1956). After 2000, this relationship shifted completely and the dominant forms seemed to be freshwater species (Catianis et al., 2018).

We aim to build a palaeobiological record from sediment cores in the RSL that shows faunal responses to past natural and human-induced environmental variation. Insight into faunal development and resilience has direct relevance for outlining conservation strategies for Pontocaspian biota. The RSL is uniquely equipped for this study as it is one of the largest areas where threatened Pontocaspian biota still occur in the Black Sea basin and contains a detailed late Holocene geological record of faunal and environmental change.

\section{Regional setting}

Over the past millennia, the RSL has evolved from a restricted marine embayment south of the Danube Delta into the highly restricted lake system of today (VespremeanuStroe et al., 2017) (Fig. 1a). Much of the restriction has been attributed to prograding beach barriers that were fed by sediments brought by longshore currents from eroding Danubian deltaic lobes in the north (Ştefănescu, 1981; Panin, 1989, 1997; Panin and Jipa, 2002; Giosan et al., 2006; Dan et al., 2009; Vespremeanu-Stroe et al., 2013). Today, the RSL contains several large and many small shallow lakes of a maximum depth of $3.5 \mathrm{~m}$ and is supplied with fresh water and sediments from the Dunavăt Branch (Rădan et al., 1999).

Small-scale human modifications have occurred in the system since the ancient Greeks dredged and modified access from the Black Sea to the ports of Istros (Histria) and Orgame (Argamum) (Breţcan et al., 2008; Romanescu, 2013; Bony et al., 2015). Major anthropogenic modifications impacted the system in the 20th century to increase freshwater aquaculture production. The digging of two channels between the RSL and the southern Danube branch during the first three decades of the 20th century and seven additional channels around 1950 (Breţcan et al., 2009; Romanescu and Cojocaru, 2010) increased river influence in the RSL. At the same time, access to the Black Sea became restricted by the closure of the Gura Portiţa outlet around 1960-1970 (Breţcan and Tâmpu, 2008; Breţcan et al., 2009). Today, the Periboina and Edighiol channels remain the only (and highly restricted) connections between Lake Sinoie and the marine realm. As a result, the RSL has considerably freshened over the past 100 years (Stănică, 2011; Catianis et al., 2018).

Prior to major anthropogenic modifications, the RSL contained a salinity gradient between the northern-central parts, dominated by fresh water, and the southern part, where elevated salinities occurred (Breţcan et al., 2009). The northerncentral part consists of the three main lakes, Razim (or Razelm), Goloviţa and Zmeica, and several marginal lakes such as Agighiol, Babadag, Cosna and Leahova. Salinities in this part of the system were reported between 0.4 and $2.5 \mathrm{~g} \mathrm{~L}^{-1}$ (Vadineanu et al., 1997). The southern part comprises the main lake, Sinoie (also known as Sinoe), and a number of shallow and smaller lakes such as Istria, Nuntasi and Edighiol. Here, salinities ranged between 0.5 and $6.5 \mathrm{~g} \mathrm{~L}^{-1}$ in the late 20th century (Vadineanu et al., 1997). Over the past decade, the entire system has become almost entirely fresh water: expeditions led by GeoEcoMar in 2017 estimated $0 \mathrm{psu}$ in the northern-central parts based on mol- 

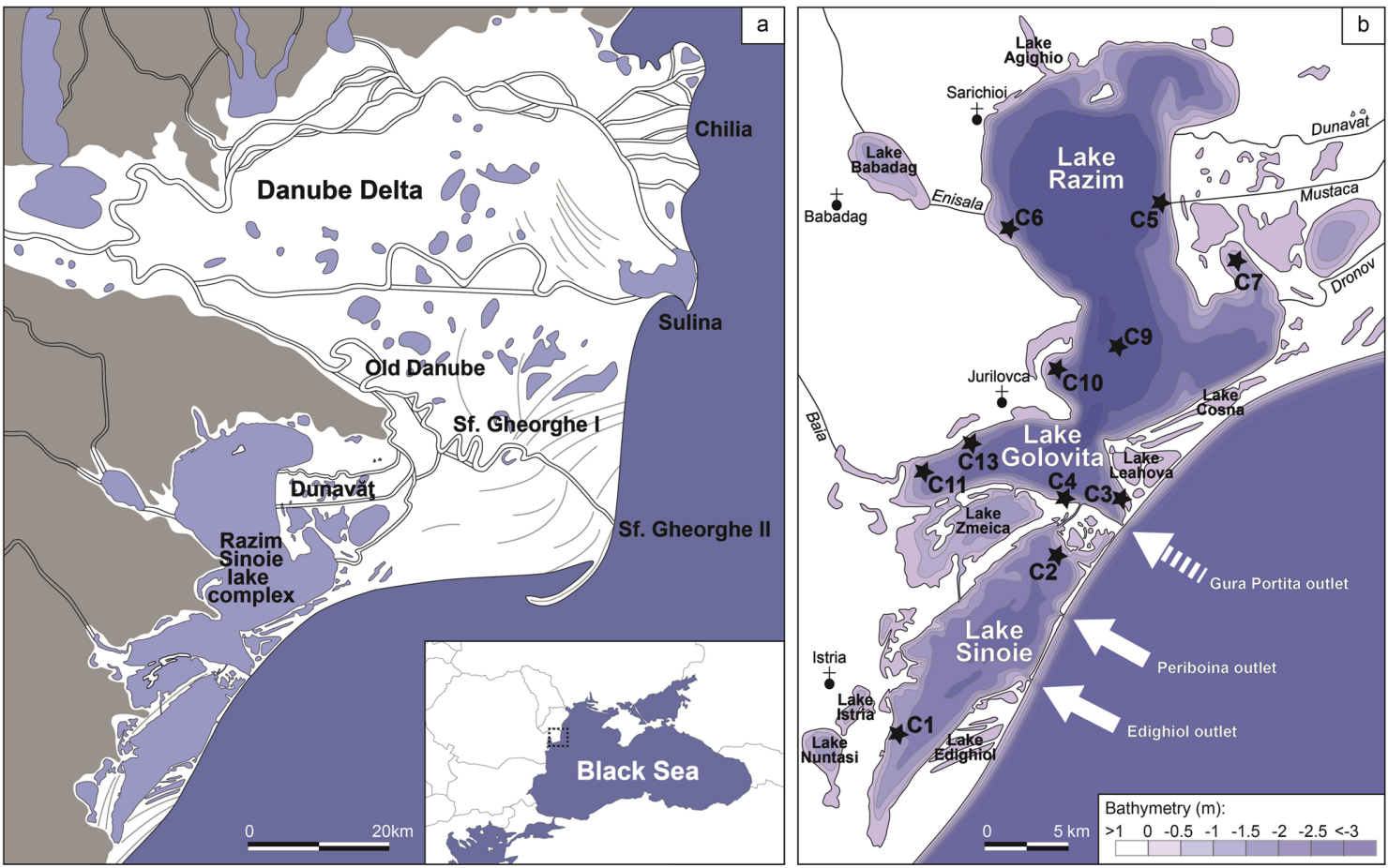

Figure 1. Location of study area along the Romanian Black Sea coast with core locations indicated by black stars. (a) Danube Delta and RSL (modified after Vespremeanu-Stroe et al., 2017). (b) RSL bathymetry with location of study cores (modified after Dimitriu et al., 2008). Two current marine outlets are indicated by white arrows; a third outlet (Gura Portiţa) was closed in the 1970s and is indicated by a dashed white arrow.

lusc species salinity tolerances and measured $0.1-0.6 \mathrm{psu}$ in the southern part (Table S1 in the Supplement). Salinity may vary seasonally depending on freshwater input from the Danube and through variations in storm activity over the Black Sea, causing additional mesohaline water to enter the RSL through the marine outlets (Breţcan et al., 2008; Dinu et al., 2015).

The RSL has been reported as prime habitat area for Pontocaspian species (Grossu, 1973; Popa et al., 2009, 2010), including endemic molluscs, ostracods, dinoflagellates, fish and crustaceans. Pontocaspian biota are a unique group of aquatic species that evolved within the Caspian Sea and Black Sea basins, as well as surrounding rivers and lakes, over the past few million years (Krijgsman et al., 2019). The basins experienced strong base-level changes and periods of isolation and connection from the open ocean, characterised by variable, anomalohaline ("brackish") conditions (Kosarev and Yablonskaya, 1994; Grigorovich et al., 2003; Kurbanov et al., 2014; Yanina, 2014). Ever since the Middle Pleistocene, during times of interglacial sea-level highstands (similar to the present day), marine conditions and faunas occupied the main Black Sea basin and pushed Pontocaspian species into coastal habitats such as deltas, lagoons and estuaries. During glacial lowstands, the Black Sea became isolated from the open ocean, freshened, and Pontocaspian biota occupied the entire basin (Krijgsman et al., 2019). Today,
Pontocaspian biota in the Black Sea basin are restricted to relatively small areas in lagoons, estuaries and deltas with salinity gradients along the coasts of Romania, Ukraine and Russia (including the Sea of Azov; Mordukhai-Boltovskoi, 1979; Anistratenko et al., 2011). Of these restricted areas, the RSL offers the largest area of Pontocaspian habitat. Pontocaspian species are currently under threat through habitat modification, pollution, poaching and invasive species (Popa et al., 2009; Shiganova, 2010; Zarbaliyeva et al., 2016).

\section{Material and methods}

We performed facies and fauna analyses on 11 shallow sediment cores. Because the RSL lakes are very shallow they do not allow for boats with piston core facilities. We manually took PVC cores with a diameter of $7.5 \mathrm{~cm}$ and lengths between 0.5 and $1.95 \mathrm{~m}$ at water depths of 1.0 to $3.5 \mathrm{~m}$ during two expeditions in October 2015 and July 2016 (Fig. 1b; Table 1). By pushing the pipes in the soft sediment and ensuring they were sealed, we were able to create a vacuum when retrieving the cores. Deformation along the core edges was minimal. Sedimentary structures like horizontal beddings were conserved within the sediments proving that the sampling method was successful and representative of changes through time and space of the depositional environment. The cores were cut lengthwise in half back in the lab- 
oratory. Analyses were performed on one half; the other half was archived in a cold room at Utrecht University.

An age model was constructed using a variety of dating methods, including ${ }^{14} \mathrm{C}$ measurements, analysis of downcore distribution of ${ }^{210} \mathrm{~Pb}$, palaeomagnetic secular variations and a known first occurrence date of an invasive species. Five samples were dated with ${ }^{14} \mathrm{C}$ measurements in the Center for Isotope Research at Groningen University. Dating results were calibrated based on a time range with a $95 \%$ probability obtained from two reservoir ages. The ${ }^{14} \mathrm{C}$ ages have been calibrated to calendar years with the software program $\mathrm{OxCal}$ version 4.3 (Ramsey, 2017), using the calibration curve IntCal13 (Reimer et al., 2013). For the late Holocene, reservoir ages have been estimated at approximately 450 to 550 years in the Danube Delta (Bonsall et al., 2004) and between 250 and 500 years in the Black Sea (Kwiecien et al., 2008). For more information on the ${ }^{14} \mathrm{C}$ dated species see Table S9.

The downcore distribution of ${ }^{210} \mathrm{~Pb}$ was assessed on four cores in the Ocean Systems Department of NIOZ, Texel. Isotopic decay of ${ }^{210} \mathrm{~Pb}$ (half-life 22.3 years) was measured via its granddaughter radionuclide ${ }^{210} \mathrm{Po}$. We applied a sampling resolution of $6 \mathrm{~cm}$ in the upper $14 \mathrm{~cm}$ of each core, and a sampling resolution of $12 \mathrm{~cm}$ below. Measurements were performed on wet-sieved $<63 \mu \mathrm{m}$ sediment fractions. Sediments were spiked with $1000 \mu \mathrm{L}$ of a standard solution of ${ }^{209} \mathrm{Po}$ and leached at $105^{\circ} \mathrm{C}$ for $6 \mathrm{~h}$ in a $10 \mathrm{~mL}$ solution of concentrated hydrochloric acid. After diluting with $40 \mathrm{~mL}$ of demineralised water and $5 \mathrm{~mL}$ of ascorbic acid, silver platelets were immersed and left in the solution at $80^{\circ} \mathrm{C}$ for $15 \mathrm{~h}$ in order to collect the natural ${ }^{210} \mathrm{Po}$ and the added ${ }^{209} \mathrm{Po}$ by spontaneous electrochemical deposition. The Po radionuclides were then counted by a Canberra alpha detector. The sediment depths with excess ${ }^{210} \mathrm{~Pb}$ decayed to below detection level were used as the age tie point of 150 years BP.

We performed palaeomagnetic analyses on core $\mathrm{C} 3$ at the Palaeomagnetic Laboratory Fort Hoofddijk at Utrecht University. Oriented $0.5 \mathrm{~cm}^{3}$ plastic cubes were pushed into the sediment core in two overlapping rows, giving an average sampling resolution of $0.5 \mathrm{~cm}$. The sediments in these cubes were then stepwise demagnetised using alternating fields (AFs) up to a maximum of $100 \mathrm{mT}$ on a robotised sample handler controller attached to a horizontal $2 \mathrm{G}$ Enterprises DC SQUID cryogenic magnetometer (Mullender et al., 2016). Changes in the magnetisation direction were recorded along the core and compared with regional archaeomagnetic data (Kovacheva et al., 1998, 2014).

Finally, the first arrival of the invasive snail Potamopyrgus antipodarum in Europe in 1859 (Ponder, 1988) provided an additional maximum age tie point. The species is originally from New Zealand, and the chronology of its introduction in other parts of the world is well known. It was introduced around 1859 to England, in 1872 to Tasmania, in 1895 to mainland Australia, in ca. 1900 to the European mainland (Ponder, 1988), and in 1987 to North America (Zaranko et al., 1997). The first reports of $P$. antipodarum from sites clos- est to the RLS come from Romania in 1951 (Son, 2008) and the Black Sea in 1952 (Gomoiu et al., 2002). As the first detection of an alien species possibly post-dates the timing of its true arrival (Crooks, 2005; Albano et al., 2018), we use the earliest known arrival date of 1859 in Europe and not the first report of arrival in the Black Sea. We checked the consistency of the age model by recalculating the model with the Black Sea arrival date to see if a possible time lag would severely affect our model and conclusions. We calculated sedimentation rates for all cores with dates available and extended the results to the remaining cores through correlation of sedimentary facies.

Sedimentary facies were characterised using lithological and sedimentological criteria and used to develop a facies model. Cores were digitally photographed and logged on a millimetre scale. Sediment colours were defined using the Munsell Soil Color Charts. Sedimentary features such as grain size variations, laminations and cross-stratification were described. Various types of inclusions were documented, such as the presence of shells, organic material and trace fossils. Detailed sedimentological observations permitted the understanding of variations in depositional energy regimes and sedimentary processes and helped to track palaeoenvironments through time.

Mollusc samples, consisting of a block of sediment of $1 \mathrm{~cm}$ thickness and $5 \mathrm{~cm}$ diameter, were taken at $6 \mathrm{~cm}$ intervals. Samples were washed and wet-sieved over a $0.5 \mathrm{~mm}$ sieve. Samples rich in fauna (estimated $>300$ specimens) were split to facilitate counting. Molluscs were identified to species level and the number of individuals for each species was counted. For bivalves, one valve was counted as half an individual, whereas for gastropods, a fragment with a protoconch was considered one individual. Final counts were rounded up to the next integer. Species were classified into groups with different salinity requirements corresponding to their different evolutionary origins (i.e. freshwater, Pontocaspian and marine) to be able to follow the threatened Pontocaspian species through time and space (Table S2).

For the current species distribution within the RSL, we used qualitative data from three expeditions carried out in 2015, 2016 and 2017 (Table S1). Van Veen grab samples and dredge samples from 77 stations obtained during a 2017 survey of GeoEcoMar (the National Institute for Research and Development of Marine Geology and Geoecology, Romania), were investigated for living molluscs. Together with the data from two surveys in 2015 and 2016 by members of the team of authors specifically in search for living Pontocaspian molluscs in the RSL, a distribution map of species was made.

We used three taphonomic criteria on the mollusc faunas to score for the fidelity of samples, i.e. fragmentation, dissolution and abrasion (details in Table S3). These characters yield information about transport, energy and post-burial processes like compaction and dissolution and may point to reworking or time-averaging of a sample (Erthal et al., 2011; Kidwell, 2013). Samples with high taphonomic alteration (any of the 
Table 1. Core data.

\begin{tabular}{llrrlrr}
\hline Expedition & Core & Latitude & Longitude & Lake & Water depth $(\mathrm{m})$ & Core length $(\mathrm{m})$ \\
\hline 2015 & $\mathrm{C} 1$ & $44.538111^{\circ} \mathrm{N}$ & $28.778583^{\circ} \mathrm{E}$ & Sinoie & 1.10 & 0.97 \\
2015 & $\mathrm{C} 2$ & $44.665944^{\circ} \mathrm{N}$ & $28.937139^{\circ} \mathrm{E}$ & Sinoie & 1.90 & 1.20 \\
2015 & $\mathrm{C} 3$ & $44.694194^{\circ} \mathrm{N}$ & $28.995028^{\circ} \mathrm{E}$ & Goloviţa & 0.80 & 1.19 \\
2015 & $\mathrm{C} 4$ & $44.698000^{\circ} \mathrm{N}$ & $28.937167^{\circ} \mathrm{E}$ & Goloviţa & 0.50 & 1.10 \\
2015 & $\mathrm{C} 5$ & $44.893472^{\circ} \mathrm{N}$ & $29.036167^{\circ} \mathrm{E}$ & Razim & 2.40 & 0.59 \\
2015 & $\mathrm{C} 6$ & $44.872722^{\circ} \mathrm{N}$ & $28.874194^{\circ} \mathrm{E}$ & Razim & 1.50 & 1.20 \\
2016 & $\mathrm{C} 7$ & $44.863889^{\circ} \mathrm{N}$ & $29.096944^{\circ} \mathrm{E}$ & Razim & 1.30 & 1.16 \\
2016 & $\mathrm{C} 9$ & $44.800000^{\circ} \mathrm{N}$ & $28.987778^{\circ} \mathrm{E}$ & Razim & 3.50 & 0.60 \\
2016 & $\mathrm{C} 10$ & $44.789167^{\circ} \mathrm{N}$ & $28.918056^{\circ} \mathrm{E}$ & Razim & 1.70 & 1.60 \\
2016 & $\mathrm{C} 11$ & $44.714444^{\circ} \mathrm{N}$ & $28.786111^{\circ} \mathrm{E}$ & Goloviţa & 1.50 & 1.92 \\
2016 & $\mathrm{C} 13$ & $44.736667^{\circ} \mathrm{N}$ & $28.844444^{\circ} \mathrm{E}$ & Goloviţa & 1.50 & 1.95 \\
\hline
\end{tabular}

three taphonomic scores higher than 3; Table S3) were excluded from statistical analyses as they are likely to represent time-averaged/mixed assemblages.

For palaeosalinity estimates, we used published autecological tolerances of species (Table S2). However, published upper-salinity tolerances are often laboratory-based or derive from the unique Baltic Sea (Zhadin, 1952) and are not very informative as to the actual preferences of species in the RSL. We therefore assigned species to their optimum salinity habitat within the system: fresh water, lower or upper oligohaline and lower or upper mesohaline (sensu Strydom et al., 2003, Table S2). The Black Sea has a salinity of $18 \mathrm{psu}$, which is used as the maximum salinity in our classification, although the salinity in the southern portion of the RSL is occasionally higher due to extensive summer evaporation (Dinu et al., 2015).

We performed a variety of multivariate analyses and statistical tests to explore the spatio-temporal species distribution and associations and test for potential associations with environmental variables. Samples with fewer than 30 specimens were excluded from the analyses to avoid the effect of small sample size on species richness.

The similarity among species compositions of individual samples was explored by means of a non-metric multidimensional scaling (nMDS). Data were square rooted and subjected to Wisconsin double standardisation, where species are first standardised by maxima and then the samples by sample totals. The nMDS was computed from a BrayCurtis dissimilarity matrix. Salinity (i.e. weighted average of species' optimum salinity per sample) and grain size (using the upper bound of each category following the Wentworth scale) were fitted as 2-D surfaces to the nMDS ordination plot to test if differences in species compositions are related to these parameters (compare Hauffe et al., 2011; Neubauer et al., 2016). The applied surface fitting uses restricted maximum likelihood estimation and an isotropic smoother employing thin-plate regression splines. For visualisation purposes, the nMDS plot was rotated so that the first axis is parallel to the salinity gradient and the second to grain size.
$K$-means partitioning was used to determine if the three evolutionary species groups correspond to ecological communities (Legendre, 2005). The data were Hellingertransformed, i.e. square-rooting the relative abundances of count data, and standardised by subtracting the mean and dividing by the standard deviation (Legendre and Gallagher, 2001; Borcard et al., 2011). This procedure has been recommended for clustering of species abundance data because it limits the influence of high abundance values (Rao, 1995; Legendre and Gallagher, 2001). We used the 20 most abundant species to avoid a bias from rare species (Borcard et al., 2011). We chose $k$ to range between 2 and 10 in order to find appropriate groups representing different environmental types. To find significant species associations, we calculated Kendall's $W$ coefficient of concordance for each of the partitioned data sets (Legendre, 2005). This method tests for the most encompassing assemblages, hence the smallest number of clusters with the largest number of positively and significantly associated species (Borcard et al., 2011). For each $k$, a global Kendall's $W$ test was run to estimate if the identified species groups were significantly associated. An a posteriori test was conducted to evaluate the contribution of each species to the groups (Legendre, 2005; Borcard et al., 2011). Species groups that were not globally significant, as well as species that were negatively or not significantly associated, were excluded. For the definition of species associations, we chose the solution with $k$ being smallest and yielding groupings that reflect ecologically consistent units.

Finally, we tested for differences between the relative abundances of each of the above-defined ecological associations per sample across facies type. A Shapiro-Wilk test was conducted to test for normality of the relative abundances per association. Since normality was rejected in all cases, we performed, for each association, a Kruskal-Wallis rank sum test to assess whether the medians of relative abundances differ globally across facies types. In addition, pairwise Wilcoxon rank sum tests were computed to test for differences in median relative abundances between individual facies. 
All analyses were performed in R v. 3.3 .3 ( $\mathrm{R}$ Core Team, 2017), using package “vegan” v. 2.4-4 (Oksanen et al., 2015)

\section{Results}

\subsection{Age model}

We obtained 13 age tie points showing that the RSL record covers slightly over 2000 years (Fig. 2, Tables S4, S9). An average sedimentation rate of $0.108 \mathrm{~cm} \mathrm{yr}^{-1}$ across the entire lake system was deduced (Table S5). Sedimentation rates are estimated at $0.083 \mathrm{~cm} \mathrm{yr}^{-1}$ for the lower parts of the cores and at $0.126 \mathrm{~cm} \mathrm{yr}^{-1}$ for the upper parts. Sedimentation rates in the RSL are high in comparison to other regional examples of Miocene-Pliocene deltaic and lacustrine environments (De Leeuw et al., 2013; Jorissen et al., 2018), which may be explained by a lack of post-depositional compaction of the sediments in these young lagoon and lacustrine sediments. We excluded admixed reworked faunas (high taphonomic scores) to reduce a possible bias in our age model. Any other bias from reworking through bioturbation and timeaveraging is very unlikely given the consistency of assemblages and observed trends. Moreover, our age model was little affected (1-5-year difference) by the use of the first arrival date of $P$. antipodarum in Europe (1859) compared to the first documented Black Sea region occurrence in 1952.

\subsection{Facies model}

We identified six facies that represent specific sedimentary processes and depositional environments (Fig. 2; Table S6). Facies F1 consists of medium-grey (GLEY 2-4/5B) silts to coarse-grained sands with many reworked millimetre-scale shell fragments. We interpret this facies as deposited under high energies in lagoon environments exposed to open marine conditions. Facies F2 is made of medium-grey (GLEY 2-5/5B) shell-rich silty clays to coarse-grained sands, with many millimetre- to centimetre-scale reworked shell fragments and complete shells. This facies is interpreted as sediments washing over sand barriers during storms or after human intervention and that have been deposited in lagoon environments. Facies 3 consists of greenish-grey (GLEY $1-5 / 10 \mathrm{Y})$ to olive-grey $(5 \mathrm{Y}-5 / 2)$ silts or clays with some millimetre-scale horizontal laminations. We interpret this facies to be deposited under fluctuating energy regimes, as a combination of suspension deposits and flood events within shallow lagoon to lacustrine environments. Facies 4 is made of olive-grey (5Y-5/2) organic-rich silts and clays. Many millimetre- to centimetre-scale terrestrial organic material fragments, including many reeds incorporated vertically or horizontally into the sediments. This facies is considered to represent low depositional energies in shallow lacustrine environments. Facies 5 consists of dark olive-grey $(5 \mathrm{Y}-3 / 2)$ to black (5Y-2.5/2) organic-rich clays. These sediments contain abundant millimetre- to centimetre-scale terrestrial or- ganic fragments, forming peat layers. We interpret this facies to represent very low-energy stagnant water bodies in swamp areas. Finally, facies 6 is made of olive-brown $(2.5 \mathrm{Y}-$ $4 / 3)$ to brown (10YR-4/3) clays without structures. We interpret this facies to be deposited under flocculation of clay particles in very low-energy environments, affected by sediment oxidation. These deposits represent the most recent sediments deposited in the lacustrine system (the active layer). The six facies highlight various depositional energies in the system. Dynamic sedimentary processes are dominant in lagoon environments with preferential deposition of shelly sands, whereas more stable sedimentary processes are prevalent in lacustrine environments with preferential deposition of organic-rich clays.

\subsection{Mollusc composition and palaeosalinity}

A total of 235 samples yielded 16587 mollusc specimens belonging to 44 species (Table S7).

Most species are typical for freshwater environments (24 species), 12 species are of marine origin, and 8 species have a Pontocaspian character (Table S2). Salinity tolerances of the latter group typically include a range from freshwater to oligohaline settings. The three species groups are present in all cores, showing variable presence through time and space (Fig. 2). The freshwater group is dominated by Dreissena polymorpha, Valvata piscinalis and Gyraulus crista. Marine species are mainly opportunistic species that live in mesohaline conditions and include Lentidium mediterraneum, Ecrobia maritima and Abra segmentum. The Pontocaspian group consists of Adacna fragilis, Clathrocaspia knipowitschii, Dreissena bugensis, Hypanis plicata, Monodacna colorata and Theodoxus spp. Most often, individual samples include a mix of the three salinity groups, while some show a $100 \%$ domination of fresh or marine species. Pontocaspian species rarely dominate a whole sample (only twice: C10 at $83 \mathrm{~cm}$ and $\mathrm{C} 13$ at $42 \mathrm{~cm}$ ).

The distribution data of extant species show an almost complete domination by freshwater species in the entire RSL (Fig. 3, Table S1). In Lake Razim, Lake Goloviţa, Lake Zmeica, as well as along the Jurilovca Canal, the main species found alive are freshwater species. The only Pontocaspian species we found in the RSL system is Monodacna colorata, and in very low numbers (1-5 individuals per station). In Lake Sinoie, very few living species were found in 2 out of 15 stations, all of which were freshwater taxa. The two field trips in 2015 and 2016 that specifically focused on finding living Pontocaspian Lymnocardiinae resulted in a few additional locations for living Monodacna colorata (Fig. 3). During our expeditions in the RSL in search for living molluscs, no other living Pontocaspian species besides Monodacna colorata were found, nor any marine species.

Our age-dated environment model shows that the salinity gradients have dynamically shifted through the system over time (Fig. 4). The southern part (cores C01-C02-C03- 

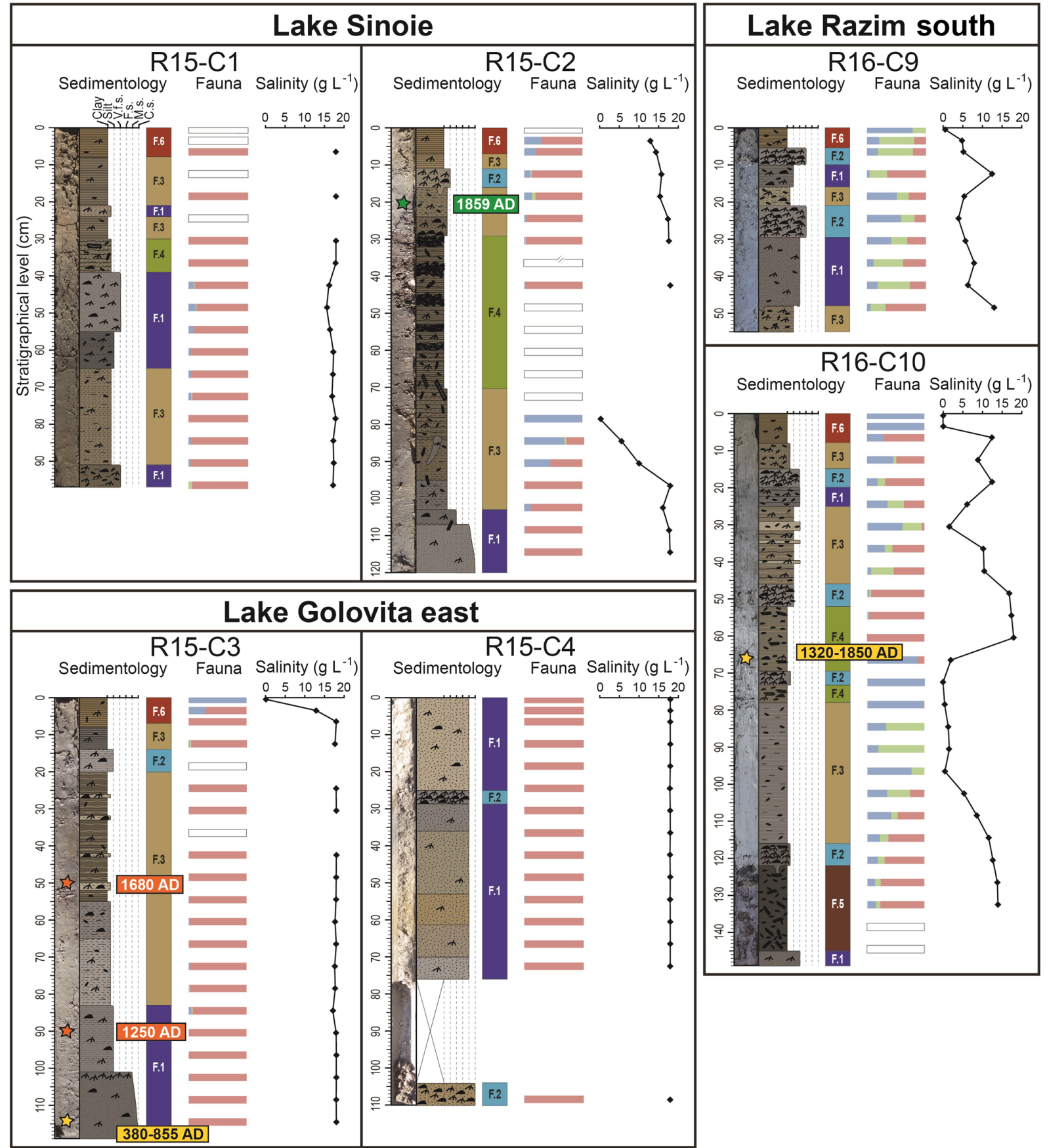

Figure 2.

C04) has maintained mesohaline conditions almost during the entire time interval. The northern part (C05-C06-C07) has been freshwater to oligohaline with intervals of increased salinities. Core 7 contains unusual high-salinity associations between $500 \mathrm{CE}$ and $1900 \mathrm{CE}$ compared to the surrounding cores. The cores taken in the centre of the system $(\mathrm{C} 09-\mathrm{C} 10$ C11-C13) show several oscillations between freshwater and mesohaline conditions. The majority of the cores indicate mesohaline conditions at the base.

\subsection{Statistical analyses}

The nMDS shows that in the 2000-year record most freshwater species lived in the northern part of the system (Razim), while the centre and south (Goloviţa and Sinoie) were dominated by species that tolerate higher salinities (nMDS stress $=0.173)($ Fig. 5, Table S8). More precisely, the southern lakes have been almost permanently occupied by mesohaline species, and freshwater species dominated the north- 


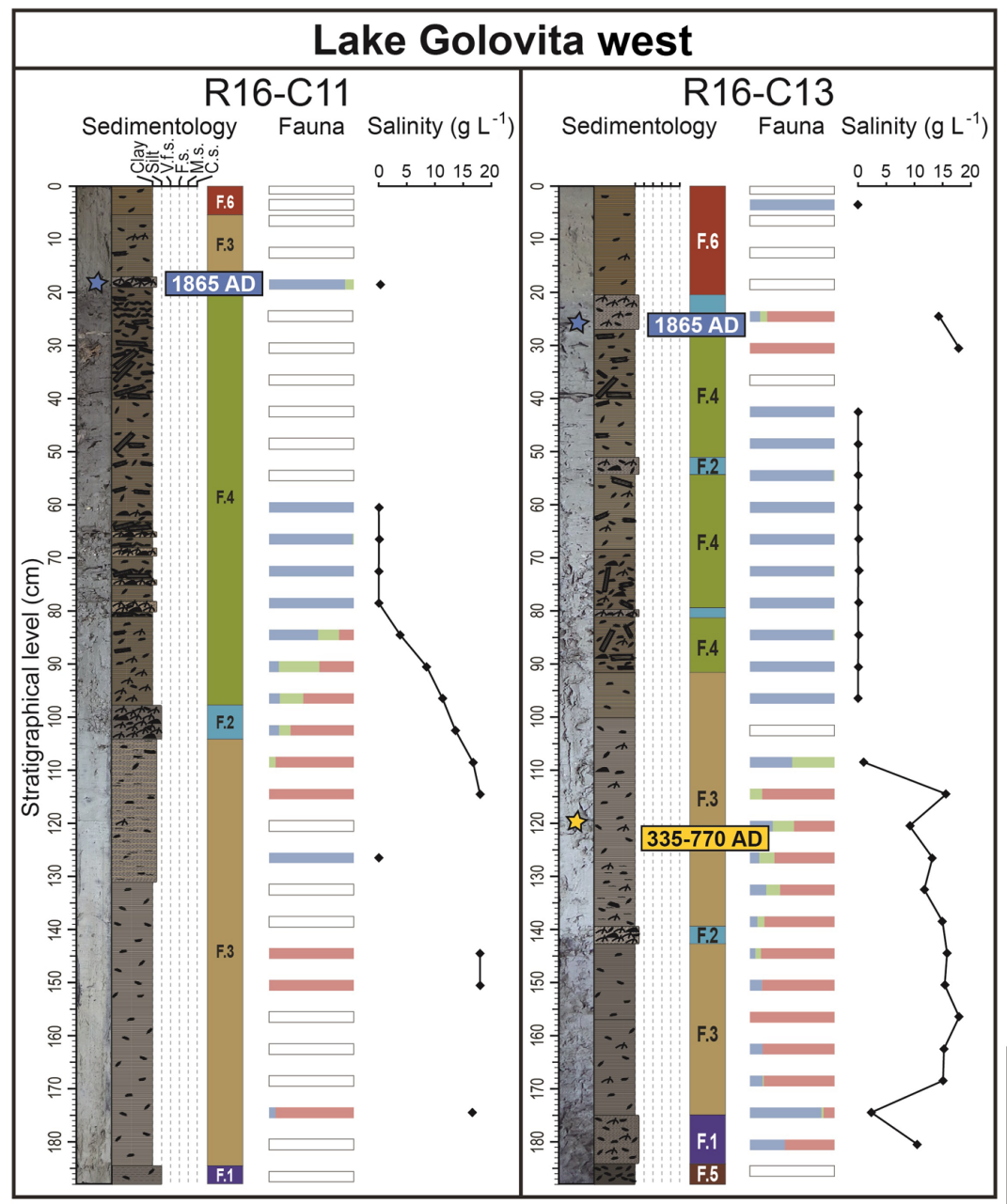

LEGEND:

SEDIMENTARY FACIES

F.1 Facies 1: sands

F.2 Facies 2: shell-rich sands

F.3 Facies 3: laminated clays/silts

F.4 Facies 4: organic-rich clays/silts

F.5 Facies 5: organic-rich black clays

F.6 Facies 6: oxidized clays

DATING METHODS

$\Leftrightarrow$ Stable isotopes ${ }^{14} \mathrm{C}$

$\Leftrightarrow$ Stable isotopes ${ }^{210} \mathrm{~Pb}$

is Magnetostratigraphy

公 Introduction of Potamopyrgus

\section{FAUNA INDICATION}

$\square$ Freshwater species

Marine species

Pontocaspian species

No data
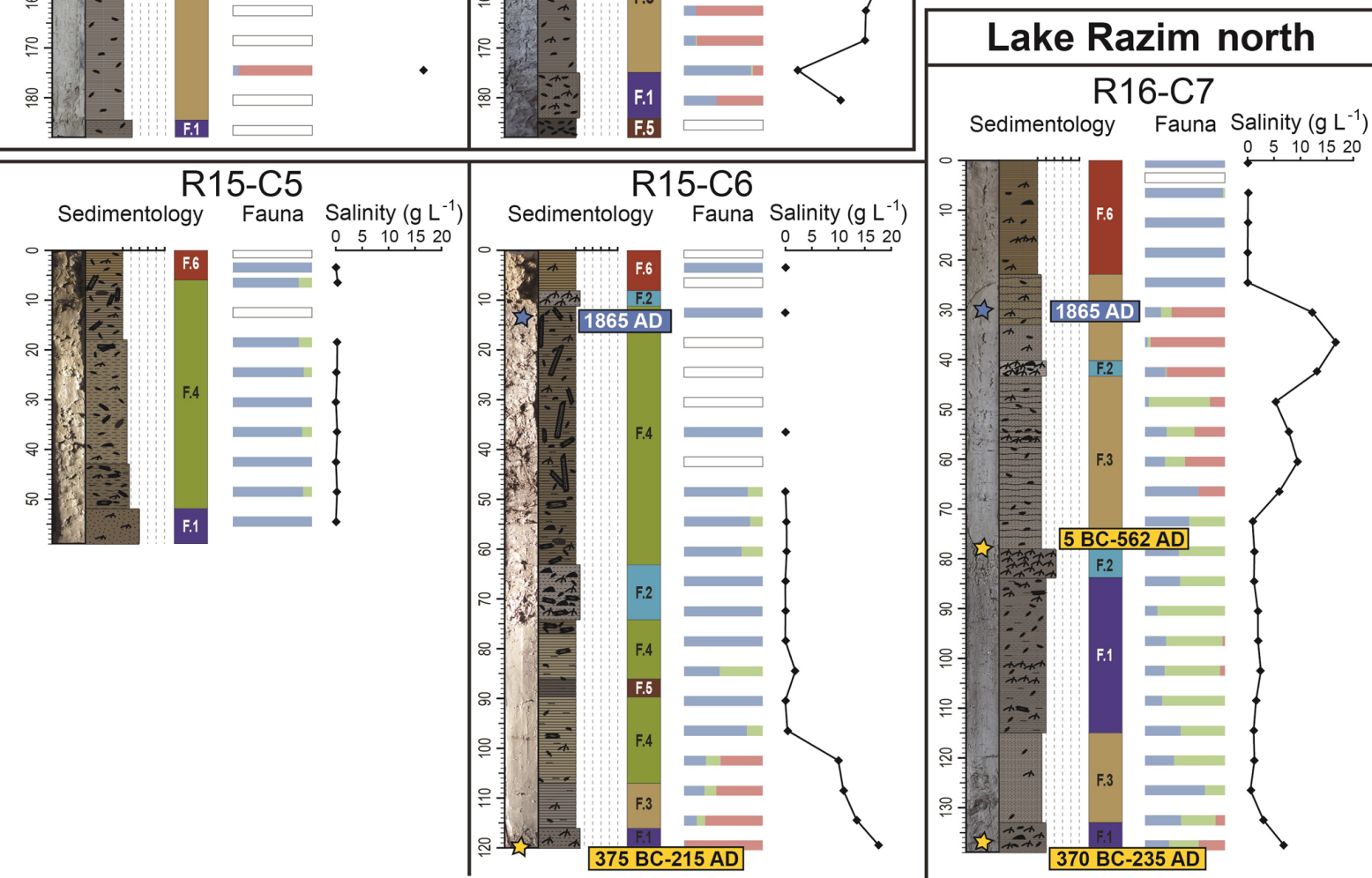

Figure 2. Overview of core data. From left to right each core: core photograph, lithology, facies, fauna relative abundance per species group based on origin, evolution and estimated palaeosalinities. 


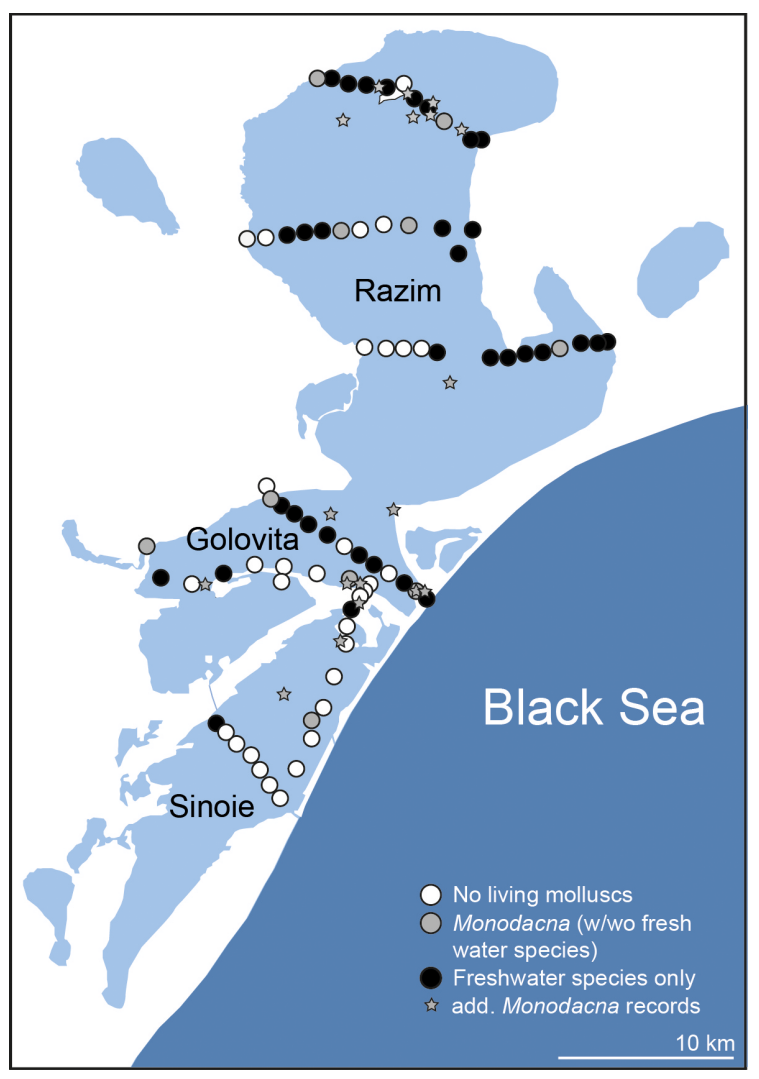

Figure 3. Sampling locations of three expeditions in 2015-2017. The first (September-October 2015) and second expeditions (July 2016) were searching for living Pontocaspian molluscs in particular. The third expedition consisted of six transects sampled by GeoEcoMar in 2017 in search of any living mollusc. In the legend w/wo means with or without.

ern part of Lake Razim and western Lake Goloviţa most of the time. Pontocaspian species occurred in various parts of the system through time, yet they were almost always present in the central-northern parts and almost entirely lacking in the southern part. The surface fitting revealed a strong association between species composition and salinity $\left(R_{\text {adj }}^{2}=0.945\right.$, deviance explained $\left.=95.1 \%, P<0.001\right)$ and, to a lesser extent, grain size $\left(R_{\mathrm{adj}}^{2}=0.533\right.$, deviance explained $=57.6 \%, P<0.001)($ Table S 8 ).

The $k$-means partitioning for two, three, four and five groups yields significant results for Kendall's $W$ coefficient of concordance; higher $k$ produced groups partly consisting of single species, which do not allow testing for concordant groups. Only for $k=2$ were all groups globally concordant; for each of $k=3$ through to $k=5$, one group was not concordant (Table S8). The a posteriori test for $k=2$ generally distinguished between a marine group (but including Potamopyrgus antipodarum and Theodoxus danubialis) and a freshwater-Pontocaspian group (Table S8). The two concordant groups identified for $k=3$ both consist of a mixed composition: one cluster was dominated by marine species, including again the freshwater species $P$. antipodarum and T. danubialis, the other one was composed of Pontocaspian species along with freshwater Dreissena polymorpha and marine Rissoa membranacea. The a posteriori test for $k=4$ identified three groups that match the groups based on species origin, with the only exceptions that the marine $R$. membranacea clustered with the Pontocaspian group (Table 2). For $k=5$, the Pontocaspian group was split up into bivalves (including the freshwater $D$. polymorpha) and a mixed gastropod group including Clathrocaspia, Rissoa and $T$. danubialis. While the marine group was still clearly demarcated, hardly any of the freshwater species were significantly associated.

Of all the clustering levels tested for, $k=4$ yielded the ecologically most consistent groupings (Fig. 6). Indicator species for Association I are Dreissena polymorpha, D. bugensis and Valvata piscinalis. The Dreissena species are filter feeding mussels that require hard/firm substrates such as shells or sticks (Gittenberger et al., 2004). Valvata piscinalis is a herbivore species that occurs on muddy bottoms in standing to slowly moving waters rich in plants (Glöer, 2002). All three species are common freshwater species but are able to tolerate salinities up to 5 psu (Glöer, 2002).

Association II is characterised by mainly Pontocaspian species, i.e. Adacna fragilis, Monodacna colorata, Hypanis plicata and Clathrocaspia knipowitschii. In general, Adacna spp. occur on muddy, rarely sandy bottoms. In the Caspian Sea, they can tolerate salinities between 4 and 14 psu (Bogutskaya et al., 2013). Monodacna colorata inhabits muddy and sandy-muddy substrates and has its optimum habitat between 0.03 and 4 psu but can tolerate higher salinities (Bogutskaya et al., 2013). Hypanis plicata is a filter feeder that prefers silty-sandy to clayey bottoms between 0.5 and $30 \mathrm{~m}$ (Bogutskaya et al., 2013). In the Caspian Sea, it prefers salinities between 4 and 8 psu (Bogutskaya et al., 2013), yet in the Black Sea, populations occur in lower salinities (Popa et al., 2009). They have also been observed in the freshwater Volga Delta (Yanina et al., 2010). Clathrocaspia knipowitschii is a herbivore gastropod that has been found at depths of $1.5-3 \mathrm{~m}$ in deltaic areas with salinities of 0 1.5 psu (Boeters et al., 2015). In addition to the Pontocaspian species, the marine grazing gastropod Rissoa membranacea clusters with this association. This species prefers 15-19 psu but can tolerate salinities below 15 psu (Rehfeldt, 1968).

Association III is defined by marine species: Mytilaster minimus, Ecrobia maritima, Cerastoderma glaucum, Abra segmentum and Parthenia interstincta. Abra, Cerastoderma and Ecrobia are capable of withstanding extreme variation in temperature and salinity between oligohaline and hypersaline (Gontikaki et al., 2003; Kevrekidis and Wilke, 2005; Kevrekidis et al., 2009). Parthenia and Mytilaster are mesohaline taxa that prefer salinities above $15 \mathrm{psu}(\mathrm{Ta}-$ ble S2).

The remaining 7 of the 20 most abundant species are either assigned to a non-concordant group or are not significantly 


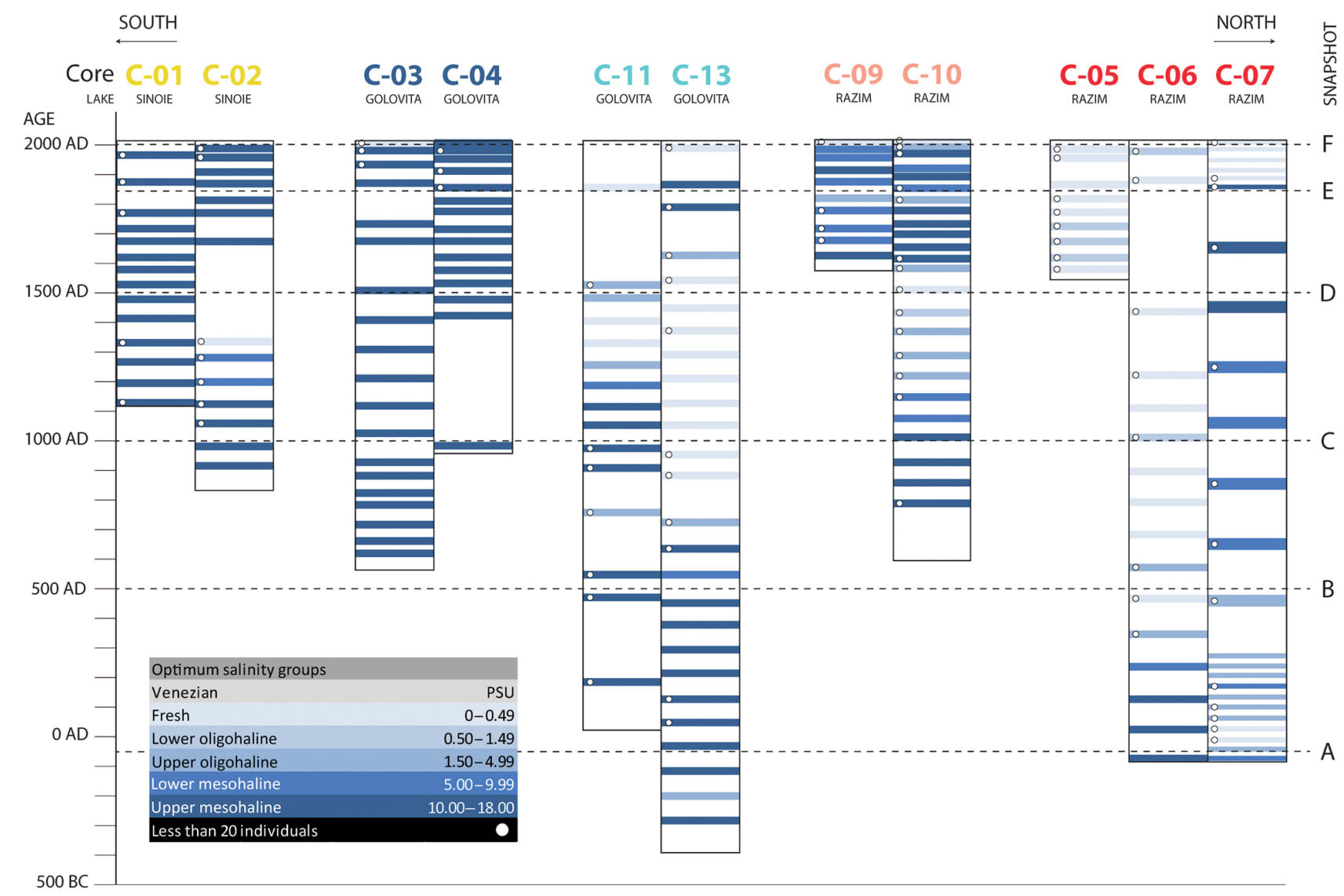

Figure 4. Spatiotemporal salinity variations in the RSL. For each sample, the salinity was calculated by weighted averaging of the species' optimum salinities. Salinity categories adapted from Strydom et al. (2003). Snapshots referred to in the Discussion are indicated with letters A-F.

associated. This outgroup contains a mixture of ecological types, including strictly marine taxa like Lentidium mediterraneum and Retusa truncatula, as well as typical freshwater species (Lithoglyphus naticoides, Gyraulus crista) and species that can tolerate a broad range of salinities (Theodoxus danubialis, T. fluviatilis, Potamopyrgus antipodarum). These species are variably assigned to different clusters in other solutions of the $k$-means clustering (Table S8), which suggests that they might not be characteristic of a specific environment or belong to ecological groups that could not be identified by our analyses.

The relative abundances of the three associations are partly related to facies type (Fig. 7). Association I is dominant in the low-energy lacustrine facies F4 and F6, the latter of which is typical of the modern setting. The marine Association III is most common in facies F3, characteristic of shallow lagoon to lacustrine environments, and F5, typical of stagnant swampy areas. In contrast, the Pontocaspian-dominated Association II is evenly distributed across all facies types. This result is also confirmed by the Kruskal-Wallis rank sum tests: Association I $\left(\chi^{2}=37.367, P<0.001\right)$ and Association III $\left(\chi^{2}=23.431, P<0.001\right)$ show significant differ- ences in the median relative abundances across facies types, while Association II does not $\left(\chi^{2}=7.751, P=0.101\right)$. Pairwise Wilcoxon tests yielded six significant differences for Association I (F1-F2, F1-F4, F1-F6, F2-F3, F3-F4, F3-F6) and three for Association III (F1-F3, F3-F4, F3-F6) (Table S8).

\section{Discussion}

\subsection{Evolution of the RSL}

We subdivided the late Holocene evolution of the RSL into six phases, represented by snapshots A-F (Fig. 4, Fig. 8). The phases are strongly related to the development of the Danube Delta (Ştefănescu, 1981; Panin, 1989, 1997; Panin et al., 2003; Giosan et al., 2006; Vespremeanu-Stroe et al., 2017), as well as modern human modifications of the RSL (Breţcan et al., 2009; Romanescu and Cojocaru, 2010). 


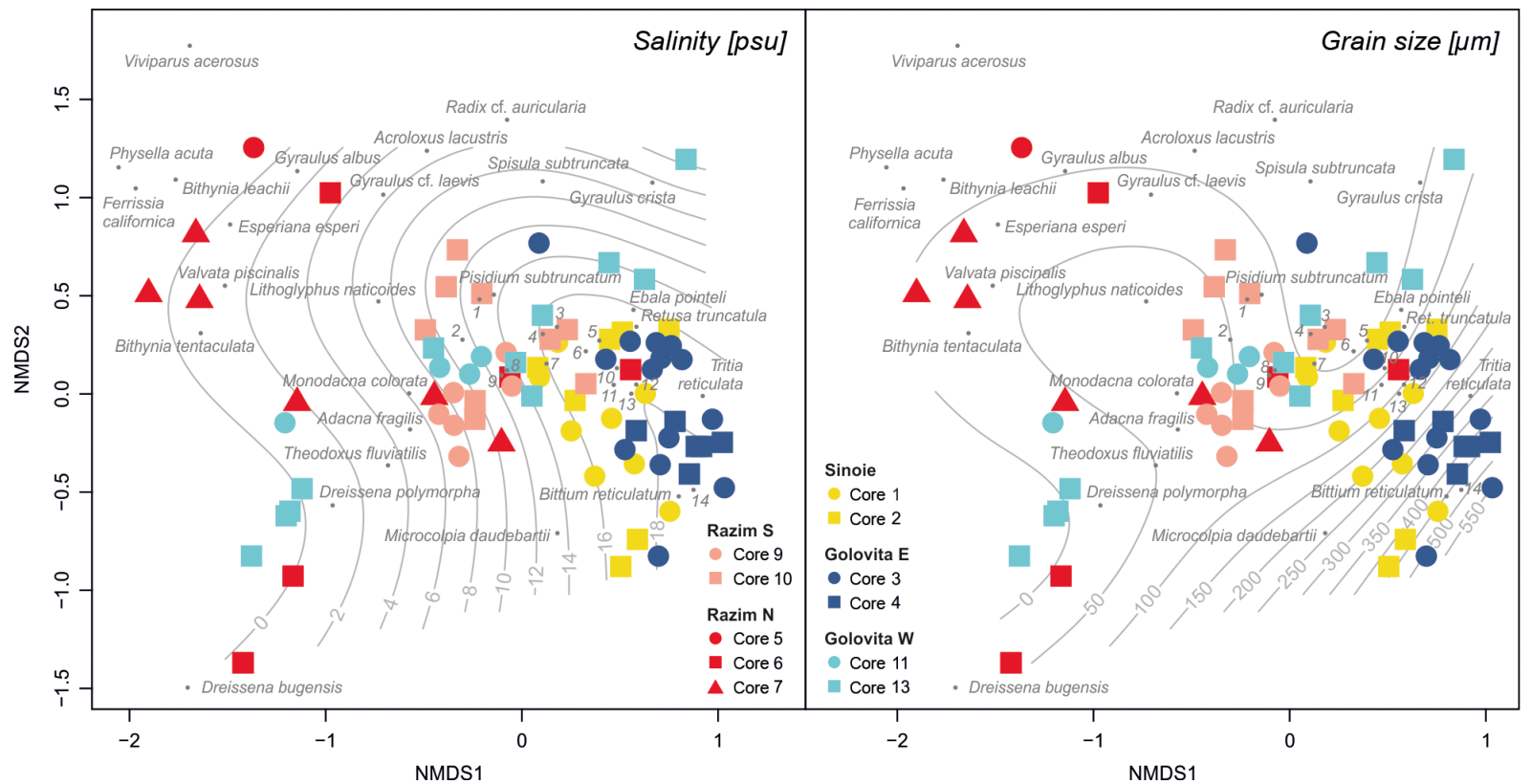

Figure 5. NMDS ordination plot of species compositions across samples grouped into lake regions (stress $=0.173$ ). Optimum salinity and grain size were fitted as two-dimensional smooth surfaces to illustrate the associations with species composition. Species are marked with numbers: 1 - Planorbis planorbis, 2 - Clathrocaspia knipowitschii, 3 - Potamopyrgus antipodarum, 4 - Theodoxus danubialis, 5 Planorbarius corneus, 6-Abra segmentum, 7 - Rissoa membranacea, 8-Valvata macrostoma, 9 - Hypanis plicata, 10 - Mytilaster minimus, 11 - Ecrobia maritima, 12 - Parthenia interstincta, 13 - Cerastoderma glaucum and 14 - Lentidium mediterraneum.

Table 2. Results of the a posteriori test of the contributions of individual species to the overall concordance of the four groups identified by $k$-means clustering at $k=4$. Provided are the mean Spearman correlations between a species and all other species in the respective group, its contribution to the overall concordance statistic $W$ for that group, the permutational probability corrected using Holm's method and the group it is associated with. Species belonging to the non-concordant group and those not significantly associated $(P>0.05)$ are marked with an asterisk. Note that, except for the outlier Rissoa membranacea, groups 1-3 correlate well with the three defined salinity groups.

\begin{tabular}{|c|c|c|c|c|}
\hline Species & Spearman mean & $W$ per species & Corrected $P$ & Group \\
\hline Dreissena polymorpha & 0.187 & 0.35 & 0.032 & 1 \\
\hline Dreissena bugensis & 0.226 & 0.381 & 0.03 & 1 \\
\hline Gyraulus crista* & 0.13 & 0.304 & 0.23 & 1 \\
\hline Lithoglyphus naticoides* & 0.16 & 0.328 & 0.175 & 1 \\
\hline Valvata piscinalis & 0.222 & 0.378 & 0.029 & 1 \\
\hline Adacna fragilis & 0.451 & 0.561 & 0.002 & 2 \\
\hline Clathrocaspia knipowitschii & 0.435 & 0.548 & 0.002 & 2 \\
\hline Hypanis plicata & 0.423 & 0.538 & 0.002 & 2 \\
\hline Monodacna colorata & 0.434 & 0.547 & 0.002 & 2 \\
\hline Rissoa membranacea & 0.36 & 0.488 & 0.002 & 2 \\
\hline Abra segmentum & 0.495 & 0.596 & 0.002 & 3 \\
\hline Cerastoderma glaucum & 0.452 & 0.561 & 0.002 & 3 \\
\hline Ecrobia maritima & 0.534 & 0.627 & 0.002 & 3 \\
\hline Mytilaster minimus & 0.336 & 0.469 & 0.002 & 3 \\
\hline Parthenia interstincta & 0.35 & 0.48 & 0.002 & 3 \\
\hline Lentidium mediterraneum $*$ & -0.064 & 0.149 & 0.83 & 4 \\
\hline Potamopyrgus antipodarum* & 0.138 & 0.311 & 0.113 & 4 \\
\hline Retusa truncatula* & 0.08 & 0.264 & 0.299 & 4 \\
\hline Theodoxus danubialis* & 0.104 & 0.283 & 0.23 & 4 \\
\hline Theodoxus fluviatilis* & 0.019 & 0.216 & 0.729 & 4 \\
\hline
\end{tabular}




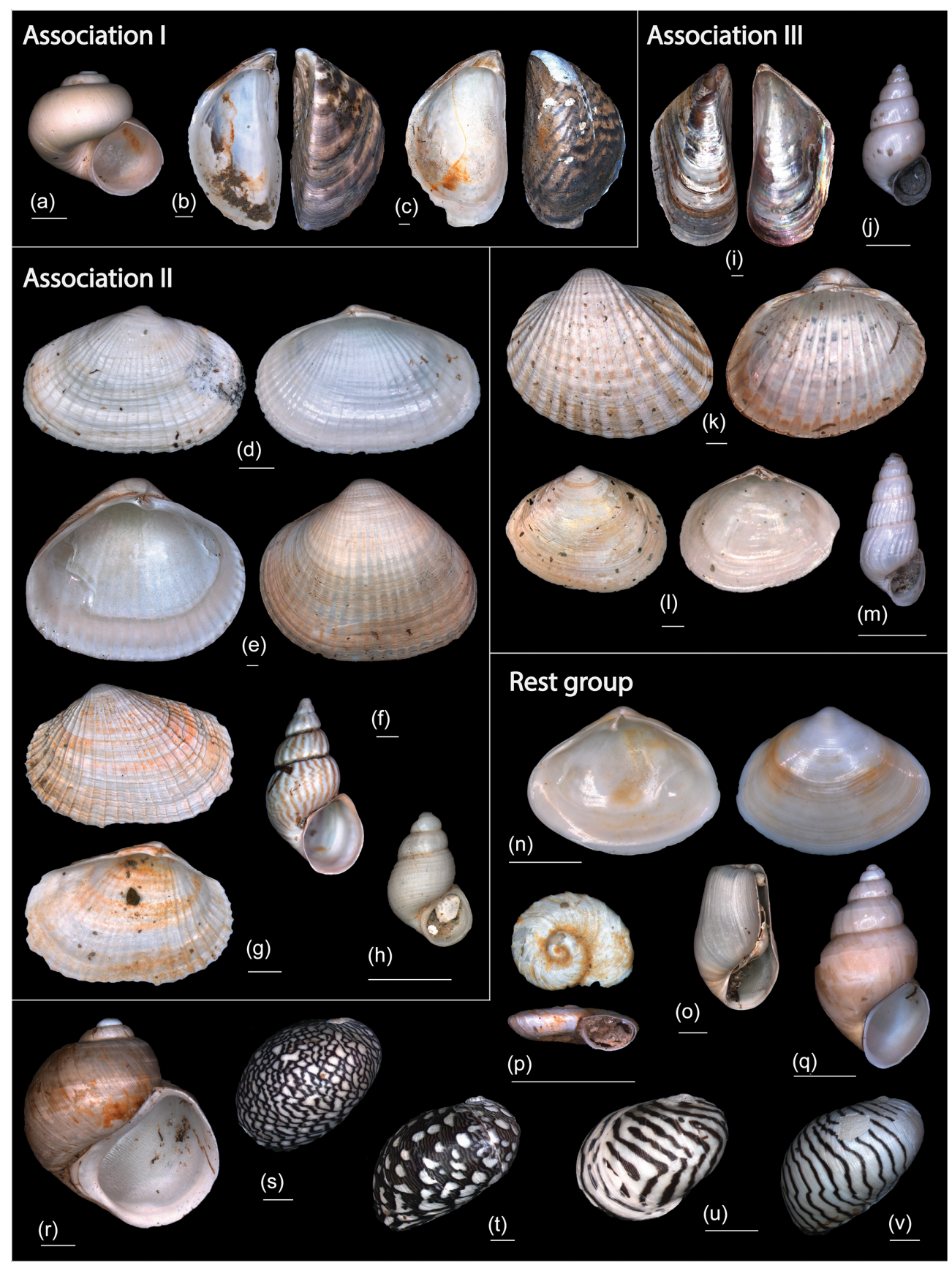

Figure 6. Overview of the 20 most abundant mollusc species grouped according to the results of Kendall's $W$ coefficient of concordance (for $k=4$ ). (a) Valvata piscinalis (RGM.1309841, Core C7, depth $6 \mathrm{~cm}$ ). (b) Dreissena polymorpha (RGM.1309827, C7 - $6 \mathrm{~cm}$ ). (c) Dreissena bugensis (RGM.1309846, C5 - 18cm). (d) Adacna fragilis (RGM.1309835, C2 - 18cm). (e) Monodacna colorata s.1. (RGM.1309823, C7 - 14 cm). (f) Rissoa membranacea (RGM.1309830, C3 - $48 \mathrm{~cm}$ ). (g) Hypanis plicata (RGM.1309845, C9 - $3 \mathrm{~cm}$ ). (h) Clathrocaspia knipowitschii (RGM.1309843, C11 - $102 \mathrm{~cm}$ ). (i) Mytilaster minimus (RGM.1309838, C3 - $24 \mathrm{~cm}$ ). (j) Ecrobia maritima (RGM.1309831, C3 - 48 cm). (k) Cerastoderma glaucum (RGM.1309844, C13 - 24 cm). (l) Abra segmentum (RGM.1309821, C1 - 48 cm). (m) Parthenia interstincta (RGM.1309832, C3 - $48 \mathrm{~cm}$ ). (n) Lentidium mediterraneum (RGM.1309837, C4 - $12 \mathrm{~cm}) .(\mathbf{o})$ Retusa truncatula (RGM.1309828, C2 - 42 cm). (p) Gyraulus crista (RGM.1309840, C5 - $54 \mathrm{~cm}$ ). (q) Potamopyrgus antipodarum (RGM.1309836, C2 $18 \mathrm{~cm}$ ). (r) Lithoglyphus naticoides (RGM.1309842, C5 - $18 \mathrm{~cm}$ ). (s) Theodoxus fluviatilis (RGM.1309826, C11 - 66 cm). (t) T. fluviatilis (RGM.1309824, C11 - $78 \mathrm{~cm}$ ). (u) Theodoxus danubialis (RGM.1309839, C3 - $24 \mathrm{~cm})$. (v) T. danubialis (RGM.1309834, C2 - 30 cm). Scale bars are $1 \mathrm{~mm}$. 

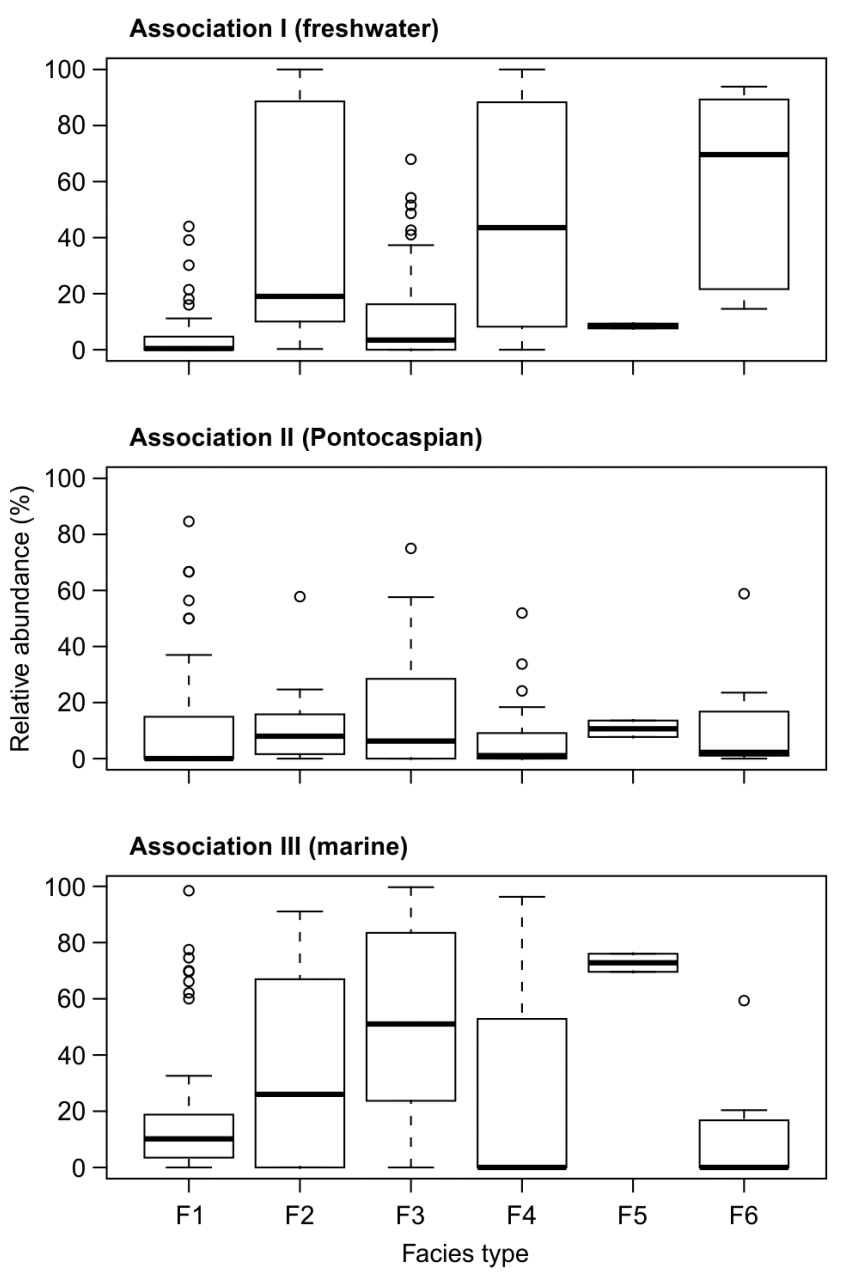

Figure 7. Box plots show the distribution of relative abundances of the associations across the six facies types.

Around 50 BCE, the RSL was a restricted embayment west of the Black Sea, formed by a barrier complex south of the Danube Delta (Fig. 8a). At that time, the Sf. Gheorghe I lobe was no longer active for the benefit of the southern Old Dunavăt (D1) lobe (Vespremeanu-Stroe et al., 2017), equivalent to the old Cosna Delta described earlier (Panin, 1989, 1997). Erosion of the deltaic lobes by strong longshore currents (Dan et al., 2009) had shaped an asymmetric wave-dominated delta in the north (Bhattacharya and Giosan, 2003; Preoteasa et al., 2016). Sediment drifting had created the Zmeica, Istria and Pahane sand barriers (Giosan et al., 2006; Bony et al., 2015; Vespremeanu-Stroe et al., 2017). The analysed facies show the separation of a protected marine bay in the west and an exposed lagoon in the north (Fig. 2). Both the presence of marine Association III species in all cores and the salinity estimations of mesohaline conditions (Fig. 4) confirm the idea of a marine bay and show that the mesohaline waters from the Black Sea dominated most of the RSL. Association I (freshwater) and Association II (Pon- tocaspian) dominated in the northeast, close to the river inflow.

The lagoon underwent further isolation from the Black Sea by a second barrier complex at ca. 500 CE (Fig. 8b). The Old Dunavăt (D1) developed into the New Dunavăt (D2) lobe (Vespremeanu-Stroe et al., 2017), corresponding to the Sinoie Delta (Panin 1997, 1989). The Lupilor (VespremeanuStroe et al., 2013) and the Saele (Bony et al., 2015) sand barriers were created by progradation of the deltaic lobe (Vespremeanu-Stroe et al., 2013). The input of fresh water from the Danube increased in the north as the RSL became increasingly isolated from the Black Sea, expressed by swamp settings in the northwest and exposed lagoon environments near outlets (Fig. 2). The relative abundance of Association III decreased, while Association I and II increased, especially in the north.

At around $1000 \mathrm{CE}$, a third barrier complex expanded the lagoon system southwards (Fig. 8c). Sediment progradation from the Sf. Gheorghe II lobe had created the Chituc sand barrier (Vespremeanu-Stroe et al., 2017) and further prolonged the Saele sand barrier (Bony et al., 2015). Together they shaped a larger lagoon system, forming the outlines of the modern lakes Razim, Goloviţa and Sinoie. The outlet became smaller and decreased the influence of the mesohaline Black Sea. Sediments deposited in the south of the system, near the main outlet, indicate exposed lagoon environments, whereas the central and northern parts of the system formed more restricted lagoon and lacustrine environments (Fig. 2). Association III (marine) shifted southwards, while Association I (freshwater) dominated near the river mouths. Association II (Pontocaspian) dominated the centre of the system.

This situation continued until the end of the Middle Ages (1500 CE), when the lagoon probably experienced strong coastal erosion causing the opening of a second outlet in the north-east (Fig. 8d). Sediment that had eroded in the north drifted southward and further prolonged the Chituc sand barrier (Vespremeanu-Stroe et al., 2017). Marine influence became larger in the northern part while maintaining river inflow from the west. A 3 -fold increase in the relative abundance of Association III and the almost complete disappearance of the Pontocaspian-dominated Association II indicate a strong turnover of species and a salinity change towards mesohaline (5-18 psu) conditions (Fig. 4). In the south, where the direct influence of the Black Sea was maintained, Association III remained dominant. The western part of the system formed a more protected shallow lacustrine environment (Fig. 2), where freshwater Association I was dominant.

Around $1850 \mathrm{CE}$, the outline of the system became very similar to the current RSL (Fig. 8e). Sediment progradation had stopped and the coast underwent strong erosion (Dan et al., 2009). Sediments deposited in Lake Sinoie are typical of shallow lagoon environments (Fig. 2) but without any input from rivers. Association III remained dominant here. The northern part of the system was a protected shallow la- 

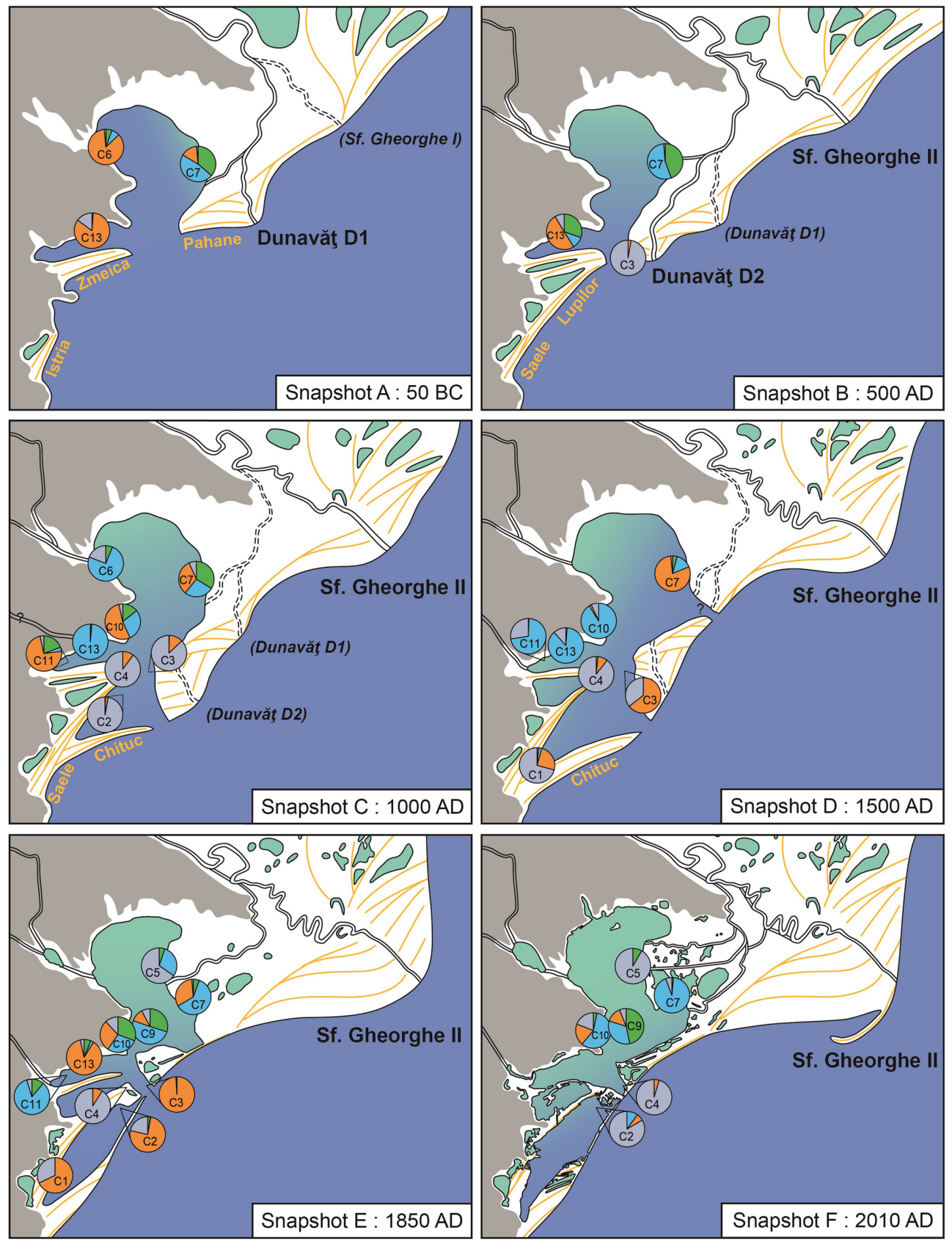

Figure 8. Snapshot reconstructions of the evolution of the RSL and their mollusc biota. The names of major sand barriers are indicated in yellow, while those of deltaic lobes are in black. The names in parentheses and italic font are currently inactive lobes. Pie charts indicate the relative abundance of the three associations in the time interval of \pm 50 years of the indicated snapshot: blue - Association I (freshwater); green - Association II (Pontocaspian), orange - Association III (marine), grey - rest of the group. Water colours indicate a salinity gradient: blue is Black Sea influence (18 psu); green is river influence $(0 \mathrm{psu})$. Note the freshening of the system and according changes in species associations with the decreasing influence of mesohaline waters from the Black Sea.

custrine environment (Fig. 2), where Association I gained in relative abundance following increased Danube inflow. Lake Goloviţa was connected to the Black Sea via the Gura Portiţa outlet but also experienced riverine influence. In this exposed lagoon environment (Fig. 2), Pontocaspian species of Association II expanded. They probably had previously found refuge in small patches in the north on the boundary between mesohaline and freshwater.

In the past century (Fig. 8f), anthropogenic activities (closure of marine outlets, opening of channels connecting to the Danube) caused a salinity decrease in the RSL (Alexandrov et al., 2004; Brețcan et al., 2009; Romanescu and Cojocaru, 
2010). Human intervention started at the beginning of the 20th century with freshening the lagoon system for economic reasons (Alexandrov et al., 2004; Breţcan et al., 2009). Two channels were dredged at the beginning of the 20th century and so were seven additional channels around 1950 in order to increase the influence of the Danube River. Around 1970, the Gura Portiţa outlet was closed to limit marine connections with the Black Sea. In Lake Razim, mollusc associations I and II dominated, while the top samples from the cores indicate a decrease in Association III in the south. Yet, a total freshening of the fauna, as seen in the current species occurrences (see below), has not yet been archived within the active layer.

During the past few years, the isolation of the RSL system led to the development of more restricted lacustrine environments with lowered salinities. Observed living mollusc occurrences show a fauna dominated by freshwater species (Fig. 3). A comparable study on fish populations in the RSL showed a similar freshening signal (Alexandrov et al., 2004).

\subsection{Optimum habitat and resilience of Pontocaspian species}

The species groups defined by evolutionary origin almost entirely correspond to ecological associations, which in turn relate to environmental settings. Species distributions shifted through the RSL in response to changes in the environment. Increasing Black Sea influence matched with decreasing freshwater species occurrences. In turn, in periods of freshening, strictly mesohaline species such as Mytilaster minimus and Parthenia interstincta disappeared.

Our analyses show various correlations between species associations and salinity and to a lesser extent grain size. In general, freshwater species are found in more mud-clay environments, marine species in sandy environments, and Pontocaspians in the transition area between clay and sand. Similar correlations between species, salinity and sediment have been demonstrated by other studies (Ysebaert and Herman, 2002; Teske and Wooldridge, 2003; Nanami et al., 2005).

Optimum Pontocaspian habitats were associated with the presence of large enough areas of freshwater to oligohaline conditions. Pontocaspian species rarely dominated the faunas and always co-occurred with either freshwater or marine species. Pontocaspian species are in general well adapted to salinity fluctuations in the freshwater to mesohaline domain (Krijgsman et al., 2019). Such conditions have existed in the RSL throughout the late Holocene. Since 2000, however, the mixed Pontocaspian assemblages gave way to freshwater assemblages (Catianis et al., 2018).

Around $1500 \mathrm{CE}$, Pontocaspian species abundances dropped throughout the RSL. The western part became dominated by freshwater species, and marine species dominated almost the entire remaining system. The increase in salinity caused by the connection to the Black Sea via the second outlet might have happened suddenly, giving room to marine species to expand and replace Pontocaspian species. Afterwards, the RSL freshened and Pontocaspian species reestablished in the central-northern parts.

Some apparent incompatibilities occur, including the presence of the marine Rissoa membranacea in the Pontocaspian community. This incompatibility may have resulted from the mixing of successive communities, e.g. by bioturbation in a single interval. Species that burrow into a layer containing well-preserved molluscs from an earlier period may yield a similar preservation status (Tomašových et al., 2019), even though we tried to avoid this influence by using taphonomic filters.

\subsection{Human impact and current species distribution}

Major human impact in the system occurred in the 20th century with the simultaneous increase in Danube input and decrease in Black Sea connectivity leading to an overall freshening of the system. Channels dug around 1900 and 1950, as well as the closure of the main marine outlet around 1970, increased the freshwater inflow from the Danube Delta and limited the marine inflow from the Black Sea into the RSL (Breţcan et al., 2008; Romanescu and Cojocaru, 2010). While the optimum Pontocaspian habitats were usually contained in the central-northern parts of the system, they have shifted throughout the whole system over the past 2000 years. However, the freshening has continued until the present day, and currently the whole complex has an estimated salinity of between 0 in the north and $0.6 \mathrm{psu}$ in the south (Table S1). This freshening has resulted in the dominance of freshwater species across the entire RSL and the almost complete disappearance of Pontocaspian species. Similar trends in community shifts in the RSL have been reported for Pontocaspian fish (Alexandrov et al., 2004).

The near-complete breakdown of the previous salinity gradient has the potential to permanently eradicate Pontocaspian habitat in the RSL. Pontocaspian biota has been able to deal with many salinity changes in the past (Krijgsman et al., 2019) but might not overcome the current situation in the RSL complex, where refuge habitats may be lacking. Previously, there was always a small salinity gradient available somewhere in the system where Pontocaspian could find refuge, but if the entire system freshens further, the remaining Pontocaspian species may face local extinction.

We see a severe decline in Pontocaspian species numbers based on the observations of living species over the past few years. The only Pontocaspian species we found living in the RSL is Monodacna colorata, which is particularly suited to surviving in lower-salinity ranges (below $4 \mathrm{psu}$; Bogutskaya et al., 2013). Very small numbers of Adacna fragilis and high numbers of living Hypanis plicata have been reported in 2007-2008 in Lake Goloviţa (Popa et al., 2009). No other Pontocaspian mollusc species have recently been reported alive in the RSL. Outside the RSL, but within the Black Sea basin, Clathrocaspia knipowitschii has been reported alive 
in 2005 in the Lower Dnieper area, Ukraine (Anistratenko, 2013).

\subsection{Conservation implications}

Since 1990, the RSL has been part of the Danube Delta Biosphere Reserve, established to preserve the genetic diversity of the local flora and fauna (Rezervatia Biosferei - Delta Dunarii 2017). Although the protection focuses on the restriction of human impact on the deltaic system today, no action has been undertaken to reduce the negative effects of past human activity. Over the past decades, Pontocaspian species occurrences and abundances have declined strongly within the RSL system. We are in need of new detailed observation campaigns that specifically target areas where Pontocaspian species were found in our cores in order to assess whether low numbers of these species locally may be present. The current study demonstrates that a restoration of previous salinity gradients by human intervention is the most likely solution to reversing the steep decline in Pontocaspian species richness and abundance. The development of dynamic barriers that allow limited and manageable influx of seawater, similar to that developed elsewhere (Banning et al., 2018) might be a strategy to be considered. Such an approach would enable restoration of the salinity gradients and dynamics in the RSL system and also enable mobile organisms such as fish to migrate between low-salinity areas in the RSL and the mesohaline Black Sea. This would benefit both the unique benthic and fish populations in the RSL.

Factors that are typically seen as negative influences on natural systems, such as projected global sea-level rise as well as increased coastal erosion following sediment starvation due to damming of the Danube Delta (Panin and Jipa, 2002), might actually be helpful in the restoration of such conditions as new outlets will be created naturally.

\subsection{The value of conservation palaeobiological case studies}

This study serves as an example of how conservation issues can be targeted by analysing a detailed palaeobiological record of environmental and faunal change. The Pontocaspian community lives within a salinity gradient and is constrained between marine and freshwater environments. Its presence can be traced through time and space in the RSL record. Our approach of using a palaeobiological record that is suitable for outlining direct conservation consequences might well be applied to other biota under pressure. Mangrove and reef slope communities are good examples: these can contain high-resolution palaeobiological records (Cramer et al., 2017). However, addressing post-depositional mixing of faunas using a taphonomic approach is required to assess the quality and fidelity of the palaeobiological record.

\section{Conclusions}

We present a palaeobiological case study of threatened Pontocaspian biota from the Razim-Sinoe lake system along the Romanian Black Sea coast. Our 2000-year record shows the existence of a Pontocaspian community that shifted through the system along salinity gradients that in turn were influenced by both natural processes and human intervention. The near-complete breakdown of the salinity gradients in the past decades corresponds with a major decline of these threatened biota. We argue for the restoration of salinity gradients in order to protect the Pontocaspian habitats and species. Documenting a palaeobiological record can only be successful when postdepositional taphonomic processes are taken into account.

Data availability. All data sets used in this publication are publicly available at the sources indicated, i.e. in this paper or in the Supplementary material of this paper.

Supplement. The supplement related to this article is available online at: https://doi.org/10.5194/bg-16-2423-2019-supplement.

Author contributions. SvdV and ELJ contributed equally to this work. FPW, WK, SvdV, ELJ and CVB designed the study; ELJ, SR, MS, ABP, AMG, SV, FPW and LP conducted fieldwork and collected the material; SvdV, ELJ, SR and ABA processed the material; ELJ, CVB and HS realised the age model; ELJ and HAA performed the sedimentological analysis; SvdV, FPW, SR, ABP and AMG identified the species; TAN and SvdV performed the statistical analysis; the manuscript was written by SvdV, ELJ, TAN and FPW with input from all co-authors. All authors gave final approval for publication.

Competing interests. The authors declare that they have no conflict of interest.

Acknowledgements. We are thankful to Andrei Briceag and Dani Grosu (GeoEcoMar, Bucharest) for assisting in the field, Piet van Gaever (NIOZ, Texel) for supporting Pb dating, Pierre Plard-Taine (UniLasalle, Beauvais) for contributing to sedimentary data acquisition, Marjan Helwerda (Naturalis Biodiversity Center, Leiden) for assisting with mollusc samples sorting, Wim Kuijper (Leiden University, Leiden) for helping with freshwater mollusc species identification, and Willem Renema (Naturalis Biodiversity Center, Leiden) for advice on statistical analyses. We thank Marius Skolka (Universitatea Ovidius Constanta, Bucharest) and Oana Popa (National Museum of Natural History "Grigore Antipa", Bucharest) for sharing information on the currently living species. Furthermore, we are grateful to Paolo G. Albano and John Birks, as well as Christoph Heinze and Gerrit Armbrecht, for their constructive comments. 
Financial support. This research is part of the PRIDE ("Pontocaspian RIse and DEmise") project, which has received funding from the European Union's Horizon 2020 research and innovation program under the Marie Skłodowska-Curie grant agreement no. 642973. Thomas A. Neubauer was supported by an Alexander-vonHumboldt Scholarship.

Review statement. This paper was edited by Christoph Heinze and reviewed by Paolo G. Albano and John Birks.

\section{References}

Albano, P. G., Filippova, N., Steger, J., Kaufman, D. S., Tomašových, A., Stachowitsch, M., and Zuschin, M.: Oil platforms in the Persian (Arabian) Gulf: Living and death assemblages reveal no effects, Cont. Shelf Res., 121, 21-34, https://doi.org/10.1016/j.csr.2015.12.007, 2016.

Albano, P. G., Gallmetzer, I., Haselmair, A., Tomašových, A., Stachowitsch, M., and Zuschin, M.: Historical ecology of a biological invasion: the interplay of eutrophication and pollution determines time lags in establishment and detection, Biol. Invasions, 20, 1417-1430, 2018.

Alexandrov, L., Zaharia, M., Ursache, C., Zaharia, T., Telembici, A., Cernisencu, I., Mircea, D., Bostina, A., and Smocov, V.: Environmental changes and their impact on fisheries in Sinoe Lagoon-Romania, Cercet. Mar., 35, 237-252, 2004.

Anistratenko, V. V.: On the taxonomic status of the highly endangered Ponto-Caspian gastropod genus Caspia (Gastropoda: Hydrobiidae: Caspiinae), J. Nat. Hist., 47, 51-64, https://doi.org/10.1080/00222933.2012.742934, 2013.

Anistratenko, V. V., Khaliman, I. A., and Anistratenko, O. Y.: Mollyuski Azovskogo morya, Kiev, Ukraine, 2011.

Banning, G. van, Baan, J. van der, and de Bruijne, W.: Vismigratierivier Afsluitdijk (Fish migration river Afsluitdijk), Zwolle, the Netherlands, 2018.

Bhattacharya, J. P. and Giosan, L.: Wave-influenced deltas: geomorphological implications for facies reconstruction, Sedimentology, 50, 187-210, 2003.

Birks, H. J. B.: Ecological palaeoecology and conservation biology: controversies, challenges, and compromises, Int. J. Biodivers. Sci. Ecosyst. Serv. Manag., 8, 292-304, https://doi.org/10.1080/21513732.2012.701667, 2012.

Boeters, H. D., Glöer, P., Georgiev, D., and Dedov, I.: A new species of Caspia Clessin et W. Dybowski, 1887 (Gastropoda: Truncatelloidea: Hydrobiidae) in the Danube of Bulgaria, Folia Malacol., 23, 177-186, https://doi.org/10.12657/folmal.023.014, 2015.

Bogutskaya, N. G., Kijashko, P. V., Naseka, A. M., and Orlova, M. I.: Identification keys for fish and invertebrates. Volume 1: Fish and molluscs, KMK Scientific Press Ltd., St. Petersburg, Moscow, Russia, 2013.

Bonsall, C., Cook, G. T., Hedges, R. E. M., Higham, T. F. G., Pickard, C., and Radovanović, I.: Radiocarbon and stable isotope evidence of dietary change from the Mesolithic to the Middle Ages in the Iron Gates: New results from Lepenski Vir, Radiocarbon, 46, 293-300, https://doi.org/10.1017/S0033822200039606, 2004.
Bony, G., Morhange, C., Marriner, N., Baralis, A., Kaniewski, D., Rossignol, I., and Lungu, V.: History and influence of the Danube delta lobes on the evolution of the ancient harbour of Orgame (Dobrogea, Romania), J. Archaeol. Sci., 61, 186-203, https://doi.org/10.1016/j.jas.2015.06.003, 2015.

Borcard, D., Gillet, F., and Legendre, P.: Numerical Ecology with R, Springer, New York, NY, USA, 2011.

Breţcan, P. and Tâmpu, M. F.: The Razim-Sinoie lacustrine complex, Protection, resources, valorization, Lakes, Reserv. Ponds, 1-2, 99-112, 2008.

Breţcan, P., Murărescu, O., Samoilă, E., Olimpia, P., and Popescu, O.: The modification of the ecological conditions in the Razim Sinoe lacuster complex as an effect of the antropic intervention, in: XXIVth Conference of the Danubian Countries on the hydrological forecasting and hydrological bases of water management, Bled, Slovenia, 2-4 June 2008, 1-13, 2008.

Breţcan, P., Murărescu, O., Samoilă, E., and Popescu, O.: Water Management in the Razim-Sinoie Lacustrine Complex, in: International Symposium on Water Management and Hydraulic Engineering, Ohrid, Macedonia, 1-5 September 2009, 791-802, 2009.

Catianis, I., Secrieru, D., Pojar, I., Grosu, D., Scrieciu, A., Pavel, A. B., and Vasiliu, D.: Water Quality, Sediment Characteristics and Benthic Status of the Razim-Sinoie Lagoon System, Romania, Open Geosci., 10, 12-33, 2018.

Cramer, K. L., O’Dea, A., Clark, T. R., Zhao, J. X., and Norris, R. D.: Prehistorical and historical declines in Caribbean coral reef accretion rates driven by loss of parrotfish, Nat. Commun., 8, 18, https://doi.org/10.1038/ncomms14160, 2017.

Crooks, J. A.: Lag times and exotic species: The ecology and management of biological invasions in slow-motion, Ecoscience, 12, 316-329, 2005.

Dan, S., Stive, M. J. F., Walstra, D. J. R., Dirk-Jan R., and Panin, N.: Wave climate, coastal sediment budget and shoreline changes for the Danube Delta, Mar. Geol., 262, 39-49, https://doi.org/10.1016/j.margeo.2009.03.003, 2009.

De Leeuw, A., Filipescu, S., Matenco, L., Krijgsman, W., Kuiper, K., and Stoica, M.: Paleomagnetic and chronostratigraphic constraints on the Middle to Late Miocene evolution of the Transylvanian Basin (Romania): Implications for Central Paratethys stratigraphy and emplacement of the Tisza-Dacia plate, Global Planet. Change, 103, 82-98, https://doi.org/10.1016/j.gloplacha.2012.04.008, 2013.

Dietl, G. P. and Flessa, K. W.: Conservation paleobiology: Putting the dead to work, Trends Ecol. Evol., 26, 30-37, https://doi.org/10.1016/j.tree.2010.09.010, 2011.

Dimitriu, R. G., Oaie, G., Gomoiu, M. T., Begun, T., Szobotka, S., Rădan, S. C., and Fulga, C.: O caracterizare interdisciplinară a stării geoecologice actuale a complexului lagunar Razelm Sinoie la începutulsecolului XXI, Geo-Eco-Marina, 14, 69-74, 2008.

Dinu, I., Umgiesser, G., Bajo, M., De Pascalis, F., Stanica, A., Pop, C., Dimitriu, R. G., Nichersu, I., and Constantinescu, A.: Modelling of the response of the Razelm-Sinoe lagoon system to physical forcing, Geo-Eco-Marina, 21, 5-18, 2015.

Erthal, F., Kotzian, C. B., and Simoes, M. G.: Fidelity of Molluscan Assemblages From the Touro Passo Formation (PleistoceneHolocene), Southern Brazil: Taphonomy As a Tool for Discover- 
ing Natural Baselines for Freshwater Communities, Palaios, 26, 433-446, https://doi.org/10.2110/palo.2010.p10-145r, 2011.

Gâstescu, P.: The Danube Delta Biosphere Reserve: Geography, biodiversity, protection and management, Rom. J. Geogr., 53, 139-152, 2009.

Giosan, L., Donnelly, J. P., Constantinescu, S., Filip, F., Ovejanu, I., Vespremeanu-Stroe, A., Vespremeanu, E., and Duller, G.: Young Danube delta documents stable Black Sea level since the middle Holocene: Morphodynamic, paleogeographic, and archaeological implications, Geology, 34, 757-760, https://doi.org/10.1130/G22587.1, 2006.

Gittenberger, E., Janssen, A. W., Kuijper, W. J., Kuiper, J. G. J., Meijer, T., Van der Velde, G., and De Vries, J. N.: De Nederlandse Zoetwatermollusken: Recente en fossiele weekdieren uit zoet en brak water, Nationaal Natuurhistorisch Museum Naturalis, Leiden, the Netherlands, 2004

Glöer, P.: Die Süßwassergastropoden Nord-und MitteleuropasBestimmungsschlüssel, Lebensweise, Verbreitung. Die Tierwelt Deutschlands, in Teil 73, 1-327, ConchBooks, Hackenheim, Germany, 2002.

Gomoiu, M. T., Alexandrov, B., Shadrin, N., and Zaitsev, Y.: The Black Sea - a recipient, donor and transit area for alien species, in: Invasive aquatic species of Europe. Distribution, impacts and management, edited by: Leppäkoski, E., Gollasch, S., and Olenin, S., Springer Science \& Business Media, Dordrecht, the Netherlands, 341-350, 2002.

Gontikaki, E., Antoniadou, C., and Chintiroglou, C. C.: Population structure of Cerastoderma glaucum and Abra ovata in Vouliagmeni Lagoon (Attiki), J. Mar. Biol. Assoc. United Kingdom, 83, 1095-1097, https://doi.org/10.1017/S0025315403008312h, 2003.

Grigorovich, I. A., Therriault, T. W., and MacIsaac, H. J.: History of aquatic invertebrate invasions in the Caspian Sea, Biol. Invasions, 5, 103-115, https://doi.org/10.1023/A:1024050824073, 2003.

Grossu, A. V.: Les Limnocardiides actuelles du bassin PontoCaspique, Société belge Malacol., 2, 123-152, 1973.

Hauffe, T., Albrecht, C., Schreiber, K., Birkhofer, K., Trajanovski, S., and Wilke, T.: Spatially explicit analysis of gastropod biodiversity in ancient Lake Ohrid, Biogeosciences, 8, 175-188, https://doi.org/10.5194/bg-8-175-2011, 2011.

Helama, S., Nielsen, J. K., and Valovirta, I.: Conchology of endangered freshwater pearl mussel: conservation palaeobiology applied to museum shells originating from northern Finland, Bolletino Malacol., 43, 161-170, 2007.

Jorissen, E. L., De Leeuw, A., van Baak, C. G. C., Mandic, O., Stoica, M., Abels, H. A., and Krijgsman, W.: Sedimentary architecture and depositional controls of a Pliocene river-dominated delta in the semi-isolated Dacian Basin, Black Sea, Sediment. Geol., 368, 1-23, https://doi.org/10.1016/j.sedgeo.2018.03.001, 2018.

Kevrekidis, T. and Wilke, T.: Life cycle, population dynamics and productivity of Ventrosia maritima in the Evros Delta (northern Aegean Sea), J. Mar. Biol. Assoc. UK, 85, 375-382, https://doi.org/10.1017/S0025315405011306h, 2005.

Kevrekidis, T., Kasapis, K., and Kalpia, V.: Life cycle, population dynamics, growth and production of Abra segmentum (Mollusca, Bivalvia) at low salinities in a Mediterranean lagoon, Helgoland Mar. Res., 63, 277-285, https://doi.org/10.1007/s10152009-0155-x, 2009.
Kidwell, S. M.: Time-averaging and fidelity of modern death assemblages: Building a taphonomic foundation for conservation palaeobiology, Palaeontology, 56, 487-522, https://doi.org/10.1111/pala.12042, 2013.

Kosarev, A. N. and Yablonskaya, E. A.: The Caspian Sea, SPB Academic Publishing, Academic Publishing, The Hague, the Netherlands, 1994.

Kosnik, M. A. and Kowalewski, M.: Understanding modern extinctions in marine ecosystems: The role of palaeoecological data, Biol. Lett., 12, https://doi.org/10.1098/rsbl.2015.0951, 2016.

Kovacheva, M., Jordanova, N., and Karloukovski, V.: Geomagnetic field variations as determined from Bulgarian archaeomagnetic data, Part II: the last 8000 years, Surv. Geophys., 19, 431-460, 1998.

Kovacheva, M., Kostadinova-Avramova, M., Jordanova, N., Lanos, P., and Boyadzhiev, Y.: Extended and revised archaeomagnetic database and secular variation curves from Bulgaria for the last eight millennia, Phys. Earth Planet. In., 236, 79-94, https://doi.org/10.1016/j.pepi.2014.07.002, 2014.

Krijgsman, W., Tesakov, A. S., Yanina, T. A., Lazarev, S., Danukalova, G., van Baak, C. G. C., Agustí, J., Alçiçek, M. C., Aliyeva, E., Bista, D., Bruch, A., Büyükmeriç, Y., Bukhsianidze, M., Flecker, R., Frolov, P., Hoyle, T. M., Jorissen, E. L., Kirscher, U., Koriche, S. A., Kroonenberg, S. B., Lordkipanidze, D., Oms, O., Rausch, L., Singarayer, J., Stoica, M., Velde, S. van de, Titov, V. V., and Wesselingh, F. P.: Quaternary time scales for the Pontocaspian domain: Interbasinal connectivity and faunal evolution. Earth-Sci. Rev., 188, 40, https://doi.org/10.1016/j. earscirev.2018.10.013, 2019.

Kurbanov, R. N., Svitoch, A. A., and Yanina, T. A.: New data on marine Pleistocene Stratigraphy of the Western Cheleken Peninsula, Dokl. Earth Sci., 459, 1623-1626, https://doi.org/10.1134/S1028334X14120265, 2014.

Kwiecien, O., Arz, H. W., Lamy, F., Wulf, S., Bahr, A., Röhl, U., and Haug, G. H.: Estimated reservoir ages of the Black Sea since the Last Glacial, Radiocarbon, 50, 99-118, https://doi.org/10.1017/S0033822200043393, 2008.

Legendre, P.: Species associations: the Kendall coefficient of concordance revisited, J. Agric. Biol. Envir. S., 10, 226-245, https://doi.org/10.1198/108571105X46642, 2005.

Legendre, P. and Gallagher, E. D.: Ecologically meaningful transformations for ordination of species data, Oecologia, 129, 271280, https://doi.org/10.1007/s004420100716, 2001.

Martinelli, J. C., Soto, L. P., González, J., and Rivadeneira, M. M.: Benthic communities under anthropogenic pressure show resilience across the quaternary, Roy. Soc. Open Sci., 4, 1-12, https://doi.org/10.1098/rsos.170796, 2017.

Mordukhai-Boltovskoi, P. D.: Composition and Distribution of Caspian Fauna in the Light of Modern Data, Int. Rev. Ges. Hydrobio., 64, 1-38, 1979.

Mullender, T. A., Frederichs, T., Hilgenfeldt, C., de Groot, L. V., Fabian, K., and Dekkers, M. J.: Automated paleomagnetic and rock magnetic data acquisition with an in-line horizontal "2G" system., Geochem. Geophy. Geosy., 17, 3546-3559, https://doi.org/10.1002/2016GC006436, 2016.

Nanami, A., Saito, H., Akita, T., Motomatsu, K. I., and Kuwahara, H.: Spatial distribution and assemblage structure of macrobenthic invertebrates in a brackish lake in relation to en- 
vironmental variables, Estuar. Coast. Shelf S., 63, 167-176, https://doi.org/10.1016/j.ecss.2004.11.004, 2005.

Neubauer, T. A., Harzhauser, M., Mandic, O., Kroh, A., and Georgopoulou, E.: Evolution, turnovers and spatial variation of the gastropod fauna of the late Miocene biodiversity hotspot Lake Pannon, Palaeogeogr. Palaeocl., 442, 84-95, https://doi.org/10.1016/j.palaeo.2015.11.016, 2016.

Oksanen, J., Blanchet, F. G., Kindt, R., Legendre, P., Minchin, P. R., O’Hara, R. B., Simpson, G. L., Solymos, P., Stevens, M. H. H., and Wagner, H.: vegan: Community Ecology Package, R package version 2.2-1, available at: http://cran.r-project.org/package= vegan (last access: 18 October 2018), 2015.

Panin, N.: Danube Delta. Genesis, evolution and sedimentology, Révue Roum. Géologie, Géophysique, Géographie, Série Géographie, 33, 25-36, 1989.

Panin, N.: On the Geomorphologic and Geologic Evolution of the River Danube-Black Sea Interaction Zone, Geo-Eco-Marina, 2, 31-40, 1997.

Panin, N. and Jipa, D.: Danube River Sediment Input and its Interaction with the North-western Black Sea, Estuar. Coast. Shelf S., 54, 551-562, https://doi.org/10.1006/ecss.2000.0664, 2002.

Panin, N., Ion, G., and Ion, E.: The Danube Delta - Chronology of lobes and rates of sediment deposition, Geo-Eco-Marina, 9-10, 8-12, 2003.

Panin, N., Tiron Dutu, L., and Dutu, F.: The Danube Delta, Méditerranée, 126, 37-54, https://doi.org/10.4000/mediterranee.8186, 2016.

Ponder, W. F.: Potamopyrgus antipodarum - a molluscan coloniser of Europe and Australia, J. Mollus. Stud., 54, 271-285, https://doi.org/10.1093/mollus/54.3.271, 1988.

Popa, O. P., Sarkany-Kiss, A., Kelemen, B. S., Iorgu, E. I., Murariu, D., and Popa, L. O.: Contributions to the knowledge of the present Limnocardiidae fauna (Mollusca, Bivalvia) from Romania, Trav. du Muséum Natl. d'Histoire Nat. "Grigore Antipa", LII (Octobre), 7-15, 2009.

Popa, O. P., Iorgu, E. I., Kelemen, B. S., Murariu, D., and Popa, L. O.: Morphometric analysis of some populations of Lymnocardiid species (Mollusca: Bivalvia) from Razelm Lake Complex (Romania), Trav. du Muséum Natl. d'Histoire Nat. "Grigore Antipa," 53, 13-19, https://doi.org/10.2478/v10191-010-0002-y, 2010.

Preoteasa, L., Vespremeanu-Stroe, A., Tătui, F., Zăinescu, F., Timar-Gabor, A., and Cîrdan, I.: The evolution of an asymmetric deltaic lobe (Sf. Gheorghe, Danube) in association with cyclic development of the river-mouth bar: Long-term pattern and present adaptations to humaninduced sediment depletion, Geomorphology, 253, 59-73, https://doi.org/10.1016/j.geomorph.2015.09.023, 2016.

Rădan, S., Ganciu, A., and Strechie, C.: Overview of the LongTerm Ecological Research Performed by GEOECOMAR in the Danube Delta, Romania, in: Proceedings of the IL TER Regional Workshop: Cooperation in Long Term Ecological Research in Central and Eastern Europe, 28 August 2012, Glasgow, UK, 101-122, 1999.

Ramsey, C. B.: Methods for summarizing radiocarbon datasets, Radiocarbon, 59, 1809-1833, 2017.

Rao, C.: A review of canonical coordinates and an alternative to correspondence analysis using Hellinger distance, Questiio, 19, 23-63, available at: https://upcommons.upc.edu/handle/2099/ 4059 (last access: 28 March 2019), 1995.
Rehfeldt, N.: Reproductive and morphological variations in the prosobranch "Rissoa membranacea", Ophelia, 5, 157-173, 1968.

Reimer, P. J., Bard, E., Bayliss, A., Beck, J. W., Blackwell, P. G., Ramsey, C. B., Buck, C. E., Cheng, H., Edwards, R. L., Friedrich, M., and Grootes, P. M.: IntCal13 and Marine13 radiocarbon age calibration curves $0-50,000$ years cal BP, Radiocarbon, 55 , 1869-1887, 2013.

Romanescu, G.: Geoarchaeology of the ancient and medieval Danube Delta: Modeling environmental and historical changes. A review, Quatern. Int., 293, 231-244, https://doi.org/10.1016/j.quaint.2012.07.008, 2013.

Romanescu, G. and Cojocaru, I.: Hydrogeological considerations on the western sector of the Danube Delta - A case study for the Caraorman and Sărăturile fluvial-marine levees (with similarities for the Letea levee), Environ. Eng. Manag. J., 9, 795-806, 2010.

Shiganova, T. A.: Biotic Homogenization of Inland Seas of the Ponto-Caspian, Annu. Rev. Ecol. Evol. S., 41, 103-125, https://doi.org/10.1146/annurev.ecolsys.110308.120148, 2010.

Son, M. O.: Rapid Expansion of the New Zealand Mud Snail Potamopyrgus antipodarum (Gray, 1843) in the Azov-Black Sea Region, Aquat. Invasions, 3, 335-340, 2008

Stănică, A.: The Danube Delta. Back to nature through international cooperation, in: Climate of Coastal Cooperation, edited by: Misdorp, R., 48-49, Coastal \& Marine Union-EUCC (Leiden, the Netherlands), available at: http://www.coastalcooperation. net/ (last access: 28 March 2019), 2011.

Ştefănescu, C. M.: Nouvelles contributions à l'étude de la formation et de l'évolution du delta du Danube: essai d'interprétation de la morphogenèse du delta à l'époque historique à partir de la toponymie, de l'histoire et des cartes anciennes, Mémoires la Sect. géographie, 10, 198 pp., 1981.

Strydom, N. A., Whitfield, A. K., and Wooldridge, T. H.: The role of estuarine type in characterizing early stage fish assemblages in warm temperate estuaries, South Africa, Afr. Zool., 38, 219-243, 2003.

Teodorescu-Leonte, R., Leonte, V., Umitru, M., and Soileanu, B.: Observations on the Razelm - Sinoie complex during 19501952, Ann. Rom. Res. Inst. Fish., 1, 1-50, 1956 (in Romanian).

Teske, P. R. and Wooldridge, T. H.: What limits the distribution of subtidal macrobenthos in permanently open and temporarily open/closed South African estuaries? Salinity vs. sediment particle size, Estuar. Coast. Shelf S., 57, 225-238, https://doi.org/10.1016/S0272-7714(02)00347-5, 2003.

Tomašových, A., Gallmetzer, I., Haselmair, A., Kaufman, D. S., Mavrič, B., and Zuschin, M.: A decline in molluscan carbonate production driven by the loss of vegetated habitats encoded in the Holocene sedimentary record of the Gulf of Trieste, Sedimentology, 66, 781-807, https://doi.org/10.1111/sed.12516, 2019.

Vadineanu, A., Cristofor, S., Ignat, G., Romanca, G., Ciubuc, C., and Florescu, C.: Changes and opportunities for integrated management of the Razim-Sinoe Lagoon system, Int. J. Salt Lake Res., 6, 135-144, https://doi.org/10.1007/BF02441890, 1997.

Vegas-Vilarrubia, T., Rull, V., Montoya, E., and Safont, E.: Quaternary palaeoecology and nature conservation: A general review with examples from the neotropics, Quaternary Sci. Rev., 30, 2361-2388, https://doi.org/10.1016/j.quascirev.2011.05.006, 2011.

Vespremeanu-Stroe, A., Preoteasa, L., Hanganu, D., Brown, A. G., Bîrzescu, I., Toms, P., and Timar-Gabor, A.: The impact of the 
Late Holocene coastal changes on the rise and decay of the ancient city of Histria (southern Danube delta), Quatern. Int., 293, 245-256, https://doi.org/10.1016/j.quaint.2012.11.039, 2013.

Vespremeanu-Stroe, A., Zăinescu, F., Preoteasa, L., Tătui, F., Rotaru, S., Morhange, C., Stoica, M., Hanganu, J., Timar-Gabor, A., Cârdan, I., and Piotrowska, N.: Holocene evolution of the Danube delta: An integral reconstruction and a revised chronology, Mar. Geol., 388, 38-61, https://doi.org/10.1016/j.margeo.2017.04.002, 2017.

Yanina, T. A.: The Ponto-Caspian region: Environmental consequences of climate change during the Late Pleistocene, Quatern. Int., 345, 88-99, https://doi.org/10.1016/j.quaint.2014.01.045, 2014.

Yanina, T. A., Svitoch, A. A., and Wesselingh, F. P.: Biodiversity of the Caspian Sea mollusks during the last $10 \mathrm{ky}$, in: Proceedings of the International Conference "The Caspian Region: Environmental Consequences of the Climate Change," 138-142, Moscow State University (MSU), Faculty of Geography, Moscow, Russia, 2010 .
Ysebaert, T. and Herman, P. M. J.: Spatial and temporal variation in benthic macrofauna and relationships with environmental variables in an estuarine, intertidal softsediment environment, Mar. Ecol. Prog. Ser., 244, 105-124, https://doi.org/10.3354/meps244105, 2002.

Zaranko, D. T., Farara, D. G., and Thompson, F. G.: Another exotic mollusc in the Laurentian Great Lakes: the New Zealand native Potamopyrgus antipodarum (Gray 1843) (Gastropoda, Hydrobiidae), Can. J. Fish. Aqu. Sci., 54, 809-814, 1997.

Zarbaliyeva, T. S., Akhundov, M. M., Kasimov, A. M., Nadirov, S. N., and Hycenova, G. G.: The influence of invasive species on the Caspian Sea aboriginal fauna in the coastal waters of Azerbaijan, Russ. J. Biol. Invasions, 7, 227-236, https://doi.org/10.1134/S2075111716030139, 2016.

Zhadin, V. I.: Mollyuski presnykh i solonovatykh vod SSSR, Izdatel'stvo Akademii Nauk SSSR, Moskva, Leningrad, Russia, 1952. 